\title{
THREATS TO SECURITY OF PROPERTY RIGHTS IN A TRANSITION ECONOMY: AN EMPIRICAL PERSPECTIVE
}

Rostislav Kapelyushnikov*, Andrei Kuznetsov**, Natalia Demina*** and Olga Kuznetsova****

Published in Journal of Comparative Economics 41(1):245-264, 2013.

DOI: $10.1016 / j . j c e .2012 .05 .00$

\footnotetext{
* State University - Higher School of Economics, Moscow

** Lancashire Business School, UK

*** Institute of World Economy and International Relations, Moscow

**** Manchester Metropolitan University Business School, UK
} 


\title{
THREATS TO SECURITY OF PROPERTY RIGHTS IN A TRANSITION ECONOMY: AN EMPIRICAL PERSPECTIVE
}

\begin{abstract}
Effective property rights protection plays a fundamental role in promoting economic performance. Yet measurement problems make the relationship between property rights and entrepreneurship an ambiguous issue. As an advancement on previous research in this paper we propose a new approach to the evaluation of the security of property rights based on direct measures that overcomes some limitations of previous studies. We apply this new metrics to a survey of manufacturing firms in Russia to identifying the economic effects associated with the lack of property protection in a transition economy. Our analysis supports the view that there is a close relationship between institutions, property rights and economic growth. Our findings confirm that redistributive risks provide a depressing effect on investment and innovative activity of manufacturing enterprises and potentially result in a huge loss in efficiency and economic growth, which in other institutional settings could have been avoided.
\end{abstract}

Keywords: property rights; economic institutions; economic growth

JEL codes: O43, P14, P26, P27

\section{Introduction}

The insecurity of property rights is widely recognised as one of the most fundamental obstacles to successful economic development (Besley and Ghatak, 2009). Inadequate protection of property rights encourages firm owners to increase spending on sheltering "their" assets and the seizure of assets held by "others" as a form of rent seeking. As a result 
resources become diverted from productive to non-productive purposes with negative consequences for investments and economic growth.

In transition economies the status of property rights acquires particular poignancy because of what Frye (2006) calls "the original sin of privatisation". It has been noted that even in countries with a long and uninterrupted tradition of democracy the privatization of once public assets creates unique legitimisation requirements because it is usually accompanied by the provision of some concessions and privileges to the new owners at a cost to the public that require justification (Moran, 2001). In transition economies on many occasions the leaders of privatization sacrificed the need to prepare a socially acceptable privatization to achieving the maximum speed and breadth of the destruction of state property (Kornai, 2000). This was done in anticipation that once control was in the hands of private owners, they will support political reforms, creating strong legal property rights (rule of law). In quite a few cases, however, reality proved to be quite different as corruption and ineffective formal institutions "made private ownership close to irrelevant" (Freeland, 2000, p. 344). According to EBRD/World Bank 1999 business environment and enterprise performance survey systematic insecurity of property rights was a feature in 22 transition economies, including Russia (BEEPS, 1999). In fact, Russia is a prime example of a country in which lack of experience of a market economy, a murky privatization, abundant natural resources and low quality of institutional environment resulted in poorly-defined and poorly-enforced property rights (Hoff and Stiglitz, 2002).

The rich literature on the security of property rights has one acknowledged weakness: there is no single universally accepted set of measurements that allow to establish the degree of 
protection (Frye, 2006). The measurement problem makes the relationship between property rights and entrepreneurship an ambiguous issue because researchers often operate with indicators that cannot be directly compared. It does not help that property rights scholars normally employ a variety of indirect indicators to measure the security of property rights.

In this paper we propose a new approach to measuring the security (strength) of property rights on a micro level and to identifying the effects associated with lack of their protection in a transition economy, using Russia as an example. The key conceptual advance is to focus on the threat of seizure of control of the firm by state or corporate agents rather than on "weaker" threats to property rights such as contract violations and regulatory predation. In our analysis we attempt to overcome some limitations of previous studies. First, in contrast to previous estimates commonly derived from such inferential characteristics of the institutional environment as the level of corruption or trust in courts, our estimates are constructed on the basis of direct data about potential redistributive threats as they are perceived by individual firms. Second, this study examines how the perception of different types of asset seizures influences the long-term choices of the firm. The paper is mainly an empirical one and provides some novel individual level data on an important topic.

The results that we obtain confirm that risks of asset seizure are a factor that may seriously undermine investment and innovative activity with negative implications for efficiency and economic growth, which could have been avoided if property rights had been better protected. This result suggests that an increase in the security of property rights remains an important resource that can substantially improve the perspectives of economic growth in countries in which property rights do not receive adequate support from the institutional 
setup. In the paper Russia serves as an example of a country in which this problem is explicit. However, the problem of security of property rights and its effect of firm's behaviour is a general one, making the implications of this study relevant for other economies, transition and developing countries in particular.

The rest of the paper is organized as follows. Section 2 discusses a conceptual background to our analysis. Section 3 presents our data and provides their descriptive analysis. Sections 4 and 5 identify major determinants of the threats to ownership in Russian manufacturing and evaluate impact of these threats on firm performance, using various econometric techniques. Section 6 concludes.

2. Conceptual Background and the Design of Empirical Analysis

Redistribution of property rights is an important and valid process that is essential for achieving market efficiency through concentration of capital in the hands of the most effective users. However, such redistribution requires the support of legal and regulatory institutions that hinder arbitrary changes in ownership following individual private or public decisions thus maintaining a level of security of property rights (Olson, 1996). Institutional failures may debase property rights and create a situation in which firm owners are more likely to pursue policies that prioritise short-term benefits over long-term returns; incentives to invest and innovate become reduced (Mauro, 1995); the structure of investments is distorted (Clarke, 2001) and assets seek safe rather than efficient applications (Dincer, 2007). 
These predictions have dramatically materialised in a Russia. The importance of investigation of property rights in the country has been emphasised by theoretical insights that draw a link between extreme inequality in the allocation of wealth, a feature of many transition economies, and the imposition of the rule of law (Shleifer, 1997). This has given an impetus for a number of theoretical studies that show how lack of secure property rights can "lock up" an economy in a "bad" equilibrium when a system with insecure property rights serves well the economic elite and remains deficient for the others (Polishchuk and Savvateev, 2004; Sonin, 2003). When the most powerful and influential owners have sufficient resources to successfully defend their assets without recourse to a public mechanism of property protection by establishing and using private mechanisms of enforcement, they have no interest in the transition to a "good" equilibrium based on effective public mechanisms. As a result, the formation of efficient institutions is blocked because they do not find sufficient demand. Worse, the economy trapped in a "bad" equilibrium with fuzzy property rights may fall into a vicious circle, going through repeated cycles of coercive asset redistribution with low growth, high inequality, and wide-spread rent-seeking.

Although protection of property rights has always been one of the main sore points of the Russian economy, empirical studies devoted to this issue are mostly limited either to a description of the various technologies of assets seizure (Radygin, 2009), or to a discussion of some "resonant" cases (such as the Yukos affair). Only few studies are based on representative micro-data or try to assess relationship between variation in the security of property rights for particular businesses and their performance (Hartarska, 2001; Hellman et al, 2000; Frye, 2002; Johnson et al, 2002; Pyle, 2007). There has been also a quantitative analysis that examines how different asset seizures have influenced the share price of firms (Goriaev and Sonin, 2005) and an examination of the types of firms especially likely to be 
targeted by state takeover (Chernykh, 2009). In any case, chronologically the available studies address the period of the late 1990s - early 2000s and do not reflect more recent developments.

\section{1. "Market" and "non-market" channels of ownership redistribution}

Methodologically our approach differs from previous analysis in several respects. We start with introducing the conjecture that reallocation of property right can be brought about through "market" and "non-market" devices. The mechanisms of market selection fall in the first category. The second embraces coercive predatory mechanisms, such as the threat of expropriation by the state, pressure coming from politically influential private agents, raider attacks supported with various forms of violence, etc. Threats of the latter kind are more likely to occur if the institutional enforcement (rule of law) is weak and open to abuse by political and economic agents (Roland and Verdie, 2003). This distinction suggests that changes in existing ownership structures would be detrimental for economic efficiency when they are provoked by "non-market" predatory mechanisms, but would promote economic efficiency if they are caused by the forces of market competition.

In practice a border-line between "market" and "non-market" channels of ownership redistribution is not clear-cut. The same action can be attributed to either category depending on the characteristics of the institutional environment in which it takes place. Hostile takeovers make a good example. They are a feature of any market economy. Although often controversial, they are widely regarded by theorists as an important element of an efficient market for corporate control that provides a mechanism both for raising shareholder value 
and for enhancing the efficiency of the corporate system as a whole (Easterbrook and Fischel, 1991). In Russia, however, hostile takeovers are driven by the raider's private benefits of control rather than by efficiency improvement considerations (Lazareva et al, 2007). They exist as a means of appropriation of property using a variety of coercive methods ranging from corruptly obtained legal documents, such as shareholders' resolutions, court judgments and state registration documents to physical violence (Firestone, 2008, 2010; Osipian, 2010). Historically this situation is rooted in shady privatisation that created conditions for continuous struggle for the redistribution of wealth between the rival groups of powerful nouveau riches. In 2000-2005 there were 6,900 hostile takeovers in Russia, 1,200 per year (Dzarasov, 2011); by comparison in the US in the last twenty years the annual average has never exceeded 19. Methods used by Russian corporate raiders exploit the failures of the existing institutions and bear substantial social cost. According to Lazareva et al (2007), this cost includes resources spent on offensive and defensive action comparable in size to the value of contested assets; costs associated with the interruption in the normal business operation and stripping the firm of its assets; weakening of incentives to invest; a tendency by major owners to accumulate an overwhelming portfolio of shares in their firms, a practice that results in low liquidity of firms' stock.

It is important to note that in Russia take-overs by private agents often do not represent "ordinary market transaction" (Chernykh, 2009). In fact, in Russia the term "hostile takeovers" has acquired an overtone that is not present in its usage in the developed countries and is mostly applied to captures assisted with various illegal and quasi-legal devices (Zhuravskaya, 2008). Also hostile takeovers are not carried out on behalf of shareholders against the will of incumbent managers because in Russia there is no separation of ownership and control as large owners either act as managers or actively supervise their companies 
(Kuznetsov et al, 2008). As a result the managers-shareholders conflict, as in the US, is virtually nonexistent and therefore a hostile takeover essentially signifies absorption against the wishes of dominant shareholders.

Attempts of re-nationalization can also interfere with market forces. In Russia it has been a feature of the last decade that the federal government and the government-controlled companies have gradually acquired majority and blocking minority stakes in a number of large companies. In 2006 alone the OECD documented as many as 29 major state acquisitions of private assets in a spectacular range of industries, including oil and gas, banking, electric power, nuclear construction, media, auto-making, machine-building, aviation, and titanium production (Chernykh, 2009). Usually, private assets are transferred to the partial or complete control of state companies that are commercial structures through the acquisition of a block of shares in a secretive deal the details of which are seldom disclosed. Considering that the owner of assets has little choice but to sell this transaction may be seen as a form of "non-market" take-over.

Analysis of "market" and "non-market" means of property redistribution must take into consideration that the focus of redistributive processes may shift with time following changes in the institutional environment. Prior to the early 2000s, for example, Russian firms were mostly deprived of access to debt as a source of financing (Shleifer and Treisman, 2001). Despite this bankruptcy proceedings were quite common, but not so much as a form of protections for debtors as an instrument of hostile takeovers by corporate raiders assisted by corrupt administrators and by corrupt courts (Stubbs, 2009). As was estimated by the Russian Federal Service for Financial Markets, by the time the 2002 Insolvency Law was enacted 
every fifth bankruptcy had the indicia of premeditated criminal actions as creditors forced the financially solvent debtors into bankruptcy in order to take control of the company's assets (Zhang, 2008). However, since then Russia's insolvency regime has undergone noticeable changes, with a number of new laws or amendments taking effect in 2008 and 2009. Orderly bankruptcy procedures have become quite common. This allowed the European Bank for Reconstruction and Development to characterise the insolvency regime in the country in 2010 as making great strides towards compliance with international best practice (EBRD, 2010). Moreover, considering the conditions of deep economic crisis that hit the country in 2008, it is appropriate to anticipate a growing proportion of bankruptcies that are results of genuine economic distress. These developments suggest that the threat of bankruptcy, which was very much a "non-market" risk that owners in Russia faced in the 1990s and the early 2000s, has acquired in the recent period features that transform it into a "market" one according to our criteria.

\subsection{Measuring the security of property rights}

We further make a distinction between "weak" forms of the insecurity of property rights, when owners are facing the threat of partial expropriation of income from their assets because of corruption, biased courts, arbitrary and unpredictable changes of regulations, etc., and "strong" forms associated with outright capture of assets and their transfer under control of others. The point is that most previous micro-level studies have dealt predominantly only with "weak" forms of ownership redistribution (Frye, 2004; Hellman and Kaufmann, 2002; Johnson et al, 2002; Pyle, 2007) whereas we focus on "strong" forms according to our terminology. 
Finally, to measure the degree of the security of property rights we introduce new nonconventional metrics. Literature admits that there are no "objective" indicators, which would allow to make such measurements with sufficient accuracy, although it is understood that such indicators should reflect both the risk of expropriation and security of contracts (Aidis et al, 2009). Most often researchers use various proxies based on general characteristics of the politico-economic environment. Thus, papers dealing with the Russian context have employed such proxies as confidence in Russian President's personal commitment to market reforms (Frye, 2004); the degree of democracy of political regimes in various Russian regions (Pyle, 2007); membership of surveyed firms in business associations (Frye, 2004; Pyle, 2007).

Since Knack and Keefer (1995) it is also common to measure the security of property rights with reference to the effectiveness of the judicial system. Indicators include such characteristics as freedom from government influence over judicial system; corruption within the judiciary; delays in receiving judicial decisions and/or enforcement; how much trust company have in the courts and whether they consider them fair and effective (Aidis et al, 2009; Frye, 2004; Hellman and Kaufmann, 2002; Johnson et al, 2002). This approach assumes that owners who perceive the formal protection of their property rights to be inadequate are more likely to doubt the fairness and impartiality of court verdicts, as well as the ability of the judiciary to enforce their verdicts. Evidence of tax avoidance and involvement of firms in bribery are also used as a mark of dissatisfaction on their part with the formal legal protection of property rights (Asoni, 2008; Hellman and Kaufmann, 2002). Finally, some authors gauge demand for private protection for this purpose (Hendley et al, 2000; Frye, 2002) or a combination of different measures (Johnson et al, 2002). 
Indirect indicators, despite their high usability, have limitations. Being "circumstantial", they measure not so much redistributive threats faced by the existing ownership structures per se as the effectiveness of possible defences against them that are available to various economic agents. A typical example is a widespread approach based on analysis of firms' perceptions of the court system. For all its usefulness it only partially reflects a general level of insecurity since the courts are not the only and very often not even the most important tool available to owners protecting their rights. On the one hand, owners may choose to deal with certain violations of property rights outside the court system even if they regard it as effective and equitable. On the other hand, some owners can successfully defend their interests through non-judicial methods in the presence of the judiciary that does not enjoy their trust.

In this study we attempt to complement previous research by employing direct measures of redistributive threats, expecting them to be more informative and accurate under certain circumstances. The measures we use are subjective probabilities of asset seizure as perceived by top managers who have immediate experience of the existing business conditions and are in a prime position to be able to estimate potential threats to existing ownership structures. In the empirical part of this research we seek to establish how these perceptions are associated with different objective characteristics of firms in Russia (e.g. size, location, form of ownership, industry, financial state, etc.), but even more importantly with local variations in institutional characteristics which traditionally were the focus of most previous studies such as the quality of the judicial system, the degree of corruption of civil servants, the level of 
administrative pressure and so on. ${ }^{1}$ This serves as a starting point for an attempt to assess the impact of both newly introduced and more conventional measures of the security of property rights on firms' long-term investment and innovation activities ${ }^{2}$.

\subsection{Problem conceptualization}

Although currently there is no developed theory of nationalization and other forms of "nonmarket" ownership redistribution, from a conceptual point of view it may be argued that under different circumstances the same factor, e.g. the firm's performance, may have very different effect on the security of property rights (Chernykh, 2009). Thus, strongly performing firms are an appealing target for nationalisation if the state seeks to boost its revenues. However, the state concerned with economic growth may choose to take over underperforming companies in order to restructure and modernise them.

We agree with the general conclusion that many of the characteristics of firms can have an ambiguous effect on the risks of seizure of assets, but believe that this argument should be put into a broader theoretical perspective. Based on the standard logic of economic analysis, the impact of various structural and performance-related characteristics on firm-specific risks of assets seizure can be best described in terms of the likely benefits and costs that may result from such seizure. In many cases these characteristics are able to cause both the benefits and

\footnotetext{
${ }^{1}$ Thus, for example, Frye (2003) has documented conspicuous variations in the degree of confidence that business people had in the judicial system in different regions of Russia.

${ }^{2}$ In this respect our approach is closest to the that by Chernykh (2009) who also analyzes the influence of various characteristics of enterprises on the risk of property redistribution. There are many differences however. Chernyck looks at realized events, a sample of Russian blue chip firms and at only one non-market risk, absorption by the state. Her analysis does not encompass the impact of the characteristics of the institutional environment on the risk of assets loss. We focus on anticipated events, rank-and-file Russian firms and consider a variety of market risks and institutional characteristics.
} 
costs either to grow or to fall simultaneously. For example, we could expect that, in Russia, raiders should target larger firms with greater export potential because of their income generation ability. At the same time, to carry out the seizure of loss-making companies or companies with zero export potential would be much easier because of the lack of large financial resources and little political influence, through which they could try to protect themselves. The existence of this trade-off has an important implication: it makes it difficult to predict theoretically the net effect of assets seizure; the end impact of many variables may only be determined empirically.

This situation is reflected in our models. They have variables of two types. The first include variables that may have predominantly a multidirectional influence on property risks. One example is the presence of the state among the shareholders. This may increase the risk of nationalisation or of establishing some form of control by local or regional authorities, but at the same time, the participation of the state may reduce the risk of raids by private agents unwilling to enter into conflict with the authorities. The second type includes variables that reflect the general state of the institutional environment. We hypothesise that they are likely to have far more unidirectional impact. These are, for example, the extent of corruption, the level of personal safety, the reliability of the judicial protection of property rights. If the first is high and the latter two are low, this creates the situation of instability that increases the cost of protecting the assets for individual owners. Of the same type is the involvement of firms in the "grey" or "shadow" economy, another common feature of the Russian business reality: it is likely to make the firm more vulnerable to potential attacks by both the state (in retaliation for tax evasion) and by private agents (as it reduces the opportunity for them to apply for legal protection in the courts and other official agencies). 
Against this conceptual background our objective is to establish if the empirical data from Russia offers support to the two hypotheses central to the current discussion on property rights:

H1: the poor quality of the institutional environment (high levels of corruption, lack of personal safety, the inefficiency of the judicial system, engagement in tax evasion, etc.) contributes to less secure property rights;

$\mathrm{H} 2$ : higher risks of property redistribution disincentivise businesses to take long-term economic decisions on such matters as investment, innovations, provision of supplier or customer credit, etc.

\section{Data and Descriptive Analysis}

We relied upon micro-data from the second round of the Russia Investment Climate Survey (ICS) of large and medium sized manufacturing firms carried out by the Higher School of Economics (HSE) in Moscow and the Levada-Center, a Moscow-based polling firm, for the Russian Ministry of Economic Development. With some amendments and modifications the questionnaire was based on the standard Business Environment Survey (now called Enterprise Surveys) that the World Bank had been conducting in many countries since 1998. The stratified random sample contained 957 firms across Russia and was representative of the population of Russian manufacturing enterprises. Selected firms were located in 48 regions and made five percent of all medium and large-sized manufacturing firms in the country. The sample does not include super-large industrial giants; the average number of employees for the participant firms is close to 600 . The survey was conducted in early 2009 , i.e., during the acute phase of the deep economic recession when most surveyed companies experienced a 
sharp deterioration in economic performance. Data collection combined standardised face-toface interviews with top-managers (either CEOs or their deputies responsible for economic, financial and commercial issues) and objective economic and financial information about firms taken from their statistical reports and balance-sheets. ${ }^{3}$

Among others, the questionnaire contained a question about potential threats related to what we call "strong" forms of the insecurity of property rights, i.e., forms that lead to seizure of companies' assets. Six possible sources of risk were mentioned in the question: incorporation into state-owned companies; take-overs by more powerful and politically more influential private companies; raider attacks; falling under control of local/regional authorities; bankruptcy; inter-corporate conflicts among major shareholders. Respondents were asked to assess the probability with which their firms could be hit by each of these eventualities on a 3-point Likert-like scale ("very probable", "more or less probable", "very improbable”).

In accordance with our understanding of developments on the Russian corporate scene one type of risks, bankruptcy, was classified as "market" and for this reason was excluded from the following analysis. It is appropriate to mention nonetheless that nearly 20 percent of respondents described the chances of bankruptcy as "very probable", which is hardly surprising considering that the survey was held at the peak of a severe economic recession.

\footnotetext{
${ }^{3}$ For a more detailed description of the sample see: Yasin et al, 2010.
} 
For each specific risk we have about $850-860$ observations, or about $90 \%$ of the total sample. The distribution of the surveyed firms by responses related to "non-market" redistributive threats is presented in Table 1. At first glance it would appear that the insecurity of property rights is not a major issue for Russian manufacturing firms as none of the identified risks was ranked as "very probable" by more than 14 percent of respondents. However, a different picture emerges if one looks at the total number of threats faced by surveyed firms as represented by the sum total of responses "very probable". Table 2 (column 2) shows that more than 35 percent of the surveyed firms stated that for them at least one of the potential threats of asset seizure was "very probable". In other words, more than a third of Russian manufacturing firms expressed belief that they were facing a high risk of losing their assets in one form or another. The situation looks even more dramatic if one considers the sum total of responses "very improbable". Mere 20 percent of the surveyed firms regarded themselves as fully protected from any threats of asset seizure (Table 2, columns 4). Thus, complete confidence in non-alienability of ownership was expressed only by one in five companies.

Table 1 about here

Table 2 also provides average number of anticipated threats (out of possible five) by probability per one firm. According to these figures, the average surveyed firm believed that it was confronted with a substantial number of very real threats (the number of "very probable" threats is 0.52 and of "more or less probable" is 2.2). These statistics paint the picture of a dangerous and aggressive business environment.

Table 2 about here

Table 3 presents pairwise correlations (Spearman's rho) between various redistributive threats. Coefficients range from 0.24 to 0.42 and are all significant at $\rho \leq 0.01$. This implies 
that in most cases firms face not one type of redistributive threats, but a whole "bundle" of them: the emergence of one threat increases the likelihood of any other.

Table 3 about here

The HSE-Levada survey also gathered data on multiple structural, ownership and performance-related dimensions of participant firms (the summary statistics are presented in Appendix, Table A1). This set of characteristics is very rich. The most relevant for our purpose are data on firm size (number of employees); year of foundation; type of location; geographical position (we distinguish 8 major regions - six Federal districts plus Moscow and Saint-Petersburg); industry (8 sectors); the intensity of competition for major products produced by the firm (low/high); sales for export (yes/no); financial condition; subsidizing by the federal government (yes/no); subsidizing by local/regional governments (yes/no); shareholding by the state (yes/no); shareholdings by foreign investors (yes/no); shareholding by firm managers (yes/no).

Even more important for our aims is that the data-set includes many characteristics that conventionally are used in the literature as proxies for the quality of the institutional environment. These are: quasi-voluntary participation in the provision of financial donations to social projects initiated by local/regional authorities; recent participation in litigations as plaintiff or defendant; confidence in the ability of the judiciary to protect contract and property rights of the firm in disputes with other firms; confidence in the ability of the judiciary to protect contract and property rights of the firm in disputes with the state; respondents' estimate of whether firms in their industry are involved in the concealment of 
sales or profits to evade tax payment ${ }^{4}$; corruption as an obstacle for doing business; threat to safety (theft, extortion, terrorism, racket, personal safety) as an obstacle for doing business. All these variables are constructed as dichotomous ${ }^{5}$ (for precise wording of the questions and construction of these variables see Table A2, Appendix).

We start the examination of the relationship between firms characteristics and the likelihood of asset seizures with simple descriptive analysis. Table 4 reveals that in Russian manufacturing both individual redistributive risks and their average numbers per firm vary significantly by groups of firms with different structural, ownership, performance-related and institutional characteristics. It implies that in Russia the market and institutional environment continues to be very diverse and firms belonging to the same industry or region may confront different combinations of redistributive risks translating into a conspicuous variation in perceived threats. The most important observation from the raw data is that redistributive risks appear to be tightly and inversely linked to the quality of institutional environment.

Table 4 about here

\section{Determinants of Redistributive Risks}

As a next step we attempt to identify in a multivariate setting major causes that might determine probabilities of asset seizure for Russian manufacturing firms with particular emphasis on the quality of the institutional environment on the assumption that weak institutions contribute to higher insecurity of property rights.

\footnotetext{
${ }^{4}$ Following conventional practice we interpret recognition of concealment of sales or profits by other firms in the industry as indirect evidence of respondents' involvement in tax evasion. 5 Some variables were recoded from initial ordinal to binary as it was found that the dichotomous format was more reliable because the gradation between Likert-scale answers was unnecessarily nuanced to be used as baseline specifications.
} 
We start with estimating a series of probit regression models for various types of redistributive threats faced by Russian manufacturing firms in which dependent variables equal 1 if a given type of threat was reported as being "very probable" and 0 if otherwise. The vector of explanatory variables consists of characteristics of the institutional environment while controls include structural, ownership and performance-related characteristics of the firms described in the previous Section.

Table 5 about here

As it follows from Table 5 of all institutional proxies lack of personal safety statistically has the strongest impact on the security of property rights. It is positively and significantly associated with probabilities of inclusion into state-owned companies, take-overs by larger and more powerful private companies, raiders' attacks and loss of assets by some shareholders as a result of inter-corporate conflicts. At the same time widespread corruption seems to activate only two types of redistributive risks - raiding and falling under control of local/regional authorities. This implies that in terms of protection of property rights the provision of personal safety and fight against crime might be more important than the containment of corruption. Engagement in tax evasion by means of concealment of the sales or profits positively correlates with all types of redistributive risks, though it reaches conventional levels of statistical significance only in the case of conflicts between major shareholders. Quasi-voluntary payments into social projects run by local or regional authorities are accompanied by higher probabilities of raiders' attacks, falling under the control of local/regional authorities as well as of conflicts among major shareholders. 
Particularly noteworthy are the effects related to the functioning of the judicial system. As it was already mentioned, in many previous studies perceptions of its fairness and effectiveness held by economic agents were used as proxies for the security of property rights. Our findings suggest that in terms of the "strong" forms of ownership redistribution associated with asset seizures the explanatory power of these measures may be modest. For instance, lack of the confidence of firms in the ability of courts to protect their contract and property rights in conflicts with other businesses often enters the estimated equations with a "wrong" (negative) sign. As Table 5 shows, the more pessimistically the surveyed firms assess their chances of success in litigation with other companies the lower is the likelihood that they could be included into state-owned companies or fall under control of local or regional authorities. However, if we turn to litigation with the state, correlation becomes positive, although statistically insignificant in most cases. Interestingly, recent litigation experience (both as plaintiffs and as defendants) intensifies at least one type of redistributive risks - the threat of inclusion into a state-owned company though the mechanism of this effect is not clear.

As for structural and performance-related characteristics, the statistically strongest relationships are found for size: the larger the firm the greater is the risk for it to be included in a state-owned company, but the lower the risk to be subjected to raider attacks or to become an arena for a conflict among major shareholders. These results do not come as a surprise: it is large and super-large companies that most often attract attention of the state but at the same time their size sometimes serve as a shield against attacks by private agents. The proxy for firms' age has little impact on redistributive risks of any type. Location provides strong impact on threats of raider attacks: firms located in rural areas face substantially 
greater risk in comparison to their counterparts in urban areas. High competition increases considerably the likelihood of take-overs by larger private companies, but appears to remains neutral to other types of risks. Export orientation substantially strengthens the security of property rights: exporters are less likely not only to be included in state-owned companies or falling under control of local/regional authorities, but also to be captured by larger and more powerful companies (which is not intuitively obvious since such firms should be much more attractive targets for take-overs). Economic performance measured by firms' financial condition correlate significantly with only one type of redistributive risks - take-overs by larger and more powerful companies. It is remarkable that this threat is higher for underperforming rather than for better performing firms. Subsidizing from the local/regional budgets predictably increases the likelihood of falling under control of local/regional authorities while subsidizing from the federal budget does not make incorporation into stateowned companies more probable.

With regard to the ownership characteristics, state ownership dramatically enhances the threats of incorporation into state-owned companies as well as becoming a target for capture by larger private firms and falling under the control of local/regional authorities. Surprisingly, contrary to expectations, foreign ownership provides no visible effects on the redistributive risks. Managerial ownership has a strong positive correlation with the risks of firms' incorporation into state-owned companies and of raider attacks.

As a next step, we repeat our econometric exercises for models with two alternative integral indices of the insecurity of property rights as dependant variables: the additive index, which is constructed as the sum total of responses "very probable" to the question about the 
probability of various redistributive risks ${ }^{6}$, and the binary one, which equals 1 if the response "very probable" was given by the firm at least once and 0 otherwise (Table 6). Vectors of explanatory variables and of controls are the same as in the models for specific redistributive risks discussed earlier.

Table 6 about here

It is worth noting that our additive index is a count variable that reflects the total number of redistributive threats. To ensure the robustness of the results to model specifications with this index we undertook analysis using two econometric techniques: OLS and a count data model. As there is overdispersion in the data, we used the negative binomial model in preference to a Poisson model (Cameron and Trivedi, 1986). ${ }^{7}$ For specification with the binary index we estimated a probit regression model. The results provided by these alternative approaches turned out to be highly consistent. We have chosen the model of negative binomial regression as our preferred specification.

As can be seen from Table 6, in this specification results for controls are close to those obtained in regressions for the specific threats to property rights. The average number of redistributive risks is significantly larger for firms partially or fully owned by the state, in

\footnotetext{
${ }^{6}$ A similar approach is used by Johnson and his co-authors who note that either of these indexes can be justified theoretically (Johnson, McMillan and Woodruff, 2002: 1340). In the context of our analysis the additive index is more appropriate if reporting more than one "very probable" risk indicates a greater level of insecurity than reporting only one. The binary index is more appropriate if the presence of one contender aiming to seize company assets has the same effect as the presence of multiple contenders.

7 In principal, we could analyze count data using multiple linear regression. But the preponderance of zeros and small values and a clearly discrete nature of the additive indicator suggested that we could improve on the linear model with Poisson or negative binomial specifications that account for these characteristics.
} 
poor financial condition, not large-sized, faced high market competition and located in the countryside. At the same time other determinants such as age, foreign or managerial shareholdings, export orientation, subsidizing from the federal or local/regional budgets appear to be not significant.

Among our institutional variables only one - confidence in the efficiency and impartiality of the courts in disputes with other enterprises - is statistically insignificant. The rest are strongly associated with the additive index of the insecurity of property rights. With other variables being equal to the sample averages, transition from high to low personal safety increases the average number of redistributive risks by 0.26 ; from a low level to a high level of corruption - by 0.11 ; from non-engagement to engagement in tax evasion - by 0.11 ; from absence to presence of recent litigation experience - by 0.12 ; from zero to active quasivoluntary "sponsorship" of social projects run by local and regional authorities - by 0.14 ; from high trust to low trust in the impartiality of the courts in disputes with the state - by 0.09 .

On the basis of estimates obtained for our preferred model we performed simulations for a "favourable" institutional environment characterised by safe and incorrupt conditions, confidence in the capacity of judiciary to defend the interests of businesses in conflicts with state or other companies, absence of the necessity to take part in frequent court litigations, non-participation in tax evasion, freedom from forced financing of social projects run by regional or local authorities and an "unfavourable" institutional environment for which characteristics are the opposite to those described above. The simulated value of the additive index of the insecurity of property rights for firms in the "favourable" institutional setup is 
0.14 whilst for firms in the "unfavourable" one it is 1.18 . This implies that in the presence of well functioning institutions firms are almost completely protected from attempts of asset seizure while in their absence such attempts becomes practically an inevitability.

For all models with the integral indices we provide robustness checks by varying explanatory or controlling variables. First, we replaced the dichotomous variable of financial condition with an alternative continuous measure of firms' performance - profit margin. Second, instead of using court characteristics, corruption and personal safety variables in binominal form we re-defined them as ordinal ones (for more details on this alternative definition, see Table A2, Appendix). Third, because of concerns associated with possible interrelatedness between measures related to the court system we estimated a series of additional specifications in which these variables were included one at a time. We re-estimated our models with these alternative sets of regressors and results remained broadly similar to those in the baseline specifications. They differed only for judicial protection against the state: defined as ordinal variable or included as a sole court characteristic it ceased to be significant at least at the 0.10 level.

The presence of multiple missing values for some variables in our data-set raises concern regarding possible selection-bias. ${ }^{8}$ To address this issue, first, we compared two sub-samples of firms, one without any missings and the other with some missings, in terms of their structural, ownership and other characteristics. The comparison did not reveal significant

\footnotetext{
${ }^{8}$ For any of our regressors the share of observations with missing values does not exceed 1015 percent. However, cumulatively this reduces the number of observations suitable for analysis to 664, or about 70 percent of the total sample. Within this sub-sample merely 27 respondents did not provide information on any redistributive risks while 55 provided it selectively on some of them.
} 
differences between these groups (Table A3, Appendix). Next, as a more rigorous test we applied the maximum likelihood estimator of Heckman model. The LR test of independency of equations (rho $=0$ ) confirmed the absence of a substantial selection bias in our results (Table A4, Appendix).

Another possible concern with our findings is the endogeneity problem. Although we use an extensive set of controls there is a possibility that the results are driven by some omitted variables. Thus, it is reasonable to assume that individuals with more pessimistic dispositions are more likely to report threats to their firm and at the same time be more critical of existing institutions. To address this eventuality, we estimated an additional specification with control for respondents' personal characteristics (their place in managerial hierarchy (CEO/non$\mathrm{CEO}$ ), tenure and some others). In this extended specification coefficients for all personal variables are insignificant while the results for institutional proxies remain virtually the same regarding both direction and size of the effects. ${ }^{9}$

On the whole our results are consistent with the hypothesis that the poor quality of the institutional environment undermines the security of property rights. Ceteris paribus, redistributive risks tend to be higher for companies that operate in an unsafe and corrupt environment, actively engage in shady dealings, are forced to "sponsor" social projects run

\footnotetext{
${ }^{9}$ As for the possibility of reverse causality, i.e., the situation in which perceived redistributive risks would affect the quality of institutions, we believe that this is plausible only in the case of very large companies with the market power great enough to influence their institutional environment. However, there were no such companies in the HSE-Levada survey. Nevertheless, as an additional robustness check, we re-estimated the model of negative binomial regression excluding 5 percent of firms with the largest number of employees. The estimations obtained for this censored sample are qualitatively similar to those for the uncensored one presented in Table 6 .
} 
by local or regional authorities and have to cope with an inefficient and unfair courts. At the same time our estimations show that to a large extent risks of asset seizure are idiosyncratic (i.e., context specific), and for this reason can only be partially captured by institutional proxies conventionally used in literature. This allows us to speculate that perceived threats to property rights may provide strong autonomous impact on firms' forward-looking decisions alongside and in addition to influences exerted by the characteristics of the general institutional environment.

5. Impact of the Insecurity of Property Rights on Firms' Economic Behaviour

As was mentioned earlier, the central theme in the literature is the impact of the insecurity of property rights proxied by various characteristics of the institutional environment on the indicators of firms' performance (mostly various measures of investment activity) (Frye, 2004; Hartarska, 2001; Johnson et al, 2002; Pyle, 2007). Firms with poorly protected property rights are more likely to suffer from short-termism and as a result are less likely to be inclined to invest in large projects; to bring about innovations; to provide supplier or customer credit; to set and pursue strategic objectives.

We test this association econometrically for Russian manufacturing firms. The HSE-Levada survey provides us with five different binary (in the format of "yes" or "no") characteristics of forward-looking decisions made by firms: performing large investments in $2008^{10}$;

${ }^{10}$ Investment was defined as large if it was more than annual depreciation or exceeded $10 \%$ of the value of fixed assets. 
implementing innovations recently; provision of customer credit ${ }^{11}$; planning investment projects for the next year; employing long-term strategic plans in the running of the company.

We take these five dummies as dependant variables where they equal 1 if a firm is involved in a particular type of economic activity and 0 otherwise and estimate for them a series of probit regression models. The vector of controls is identical to that in Section 4. As explanatory variables we use both specific threats to the security of property rights and their integral indices in two alternative formats - additive and dichotomous. Multiplicity of specifications serves as a robustness check for results that we obtain. Additionally we include in these models general characteristics of institutional environment conventionally used in the empirical literature on this subject.

We start with the examination of specifications that use specific redistributive threats as explanatory variables. Overall we estimated a series of 25 probit-regressions (5for each type of redistributive threats); however, for simplicity in Table 7 we display marginal effects only for variables, representing redistributive threats, and omit findings for other determinants. The results are mixed. Though for most individual threats coefficients have an expected negative sign, only a few of them are significant. The most important in terms of forwardlooking economic behavior seem to be inter-corporate conflicts between major shareholders while the least significant are raider attacks. The apprehension of inclusion into state-owned companies, of being absorbed by larger and more powerful companies or of falling under control of local or regional authorities also exerts visible depressive impact on firms' forward-looking decisions. However, the firm may face simultaneously more than one

\footnotetext{
${ }^{11}$ This measure was first proposed by Frye (2004).
} 
redistributive risk. Consequently, even the risks that have been found to be insignificant on their own may contribute to the cumulative destabilizing effect that insecurity of property rights inflicts on its investment and innovative activity.

To test this proposition we turn to models with the integral indices (both additive and binary) (Tables 8 and 9). The results from these specifications are well in line with each other. In all cases risk variables enter estimated equations with a "correct" (negative) sign and only in one case - provision of customer credit - do not reach standard levels of statistical significance (in specification with the additive index). This indicates that the stronger the risk of capture of assets in all its forms, the greater the likelihood that the company would avoid large investment projects, would not innovate, not lend to their customers, not have large investment projects and would not practice strategic planning.

Tables 7 and 8 about here

In specifications with the additive index (Table 8) the presence of one extra redistributive risk increases the probability that the firm did not implement large investment and did not carry out any innovations by 6 percentage points in each case. At the same time the probability that it had no investment projects for the next year increases by 5 percentage points and the probability that it does not practice strategic planning - by 6 points. In addition, it follows from the specification with the binary index that the presence of at least one "non-market" redistributive risk dramatically, by 11 percentage points, weakens the willingness of a firm to provide customer credit (Table 9). 
It is logical to assume that the combined impact of multiple redistributive risks is likely to be even more depressive than the estimates of marginal effects indicate. To verify this supposition we used coefficients obtained in the models with the additive index and performed simulations for two polar groups of firms - "completely protected from redistributive threats" (additive index $=0$ ) and "completely unprotected from redistributive threats" (additive index $=5$ ). The simulations reveal that as a result of moving from the "completely protected" category to "completely unprotected" the firm is likely to see the probabilities of making large investment decreasing by 20 percentage points, of implementing innovations by 17 , of having investment projects for the next year by 20 and of practicing of strategic planning by 18 percentage points. This is evidence that redistributive threats have profound influence on firms' long-term growth and, as a consequence, are important factors of economic development.

The estimation outcomes for institutional proxies are less straightforward. Regression coefficients for these variables are mostly insignificant and in many cases have "wrong" (positive) signs. These findings are robust to alternative specifications and observed in regressions with both additive and binary integral indices. Cases when we get statistically significant results with a "correct" (negative) sign are few and include the impact of low confidence in judicial protection in disputes with the state on innovations and strategic planning (in specifications with the additive index) and the impact of lack of personal safety on future investment (in specification with the binary index). The positive effects are more difficult to rationalise, although some are liable to a plausible interpretation. One example is the positive effect of tax evasion on future investments: this might be a reflection of a tendency to re-invest a part of revenues concealed from tax authorities which is quite usual 
for many Russian firms. ${ }^{12}$ However, offering a rational interpretation of the alleged positive effect of perceived partiality/inefficiency of the judicial system on firms' propensity to provide customer credits does not look as a feasible task and appears to be spurious. As a general conclusion, our analysis suggests that idiosyncratic risks of asset seizures are better predictors of firms' investment and innovative performance than general characteristics of institutional environment - at least in the case of Russian manufacturing. Of course, the fact that these more conventional measures of the insecurity of property rights turned out insignificant may very well be just a feature of our sample, so it is not clear whether these results are generalizable.

Next, we implemented robustness checks by varying explanatory variables. For this we performed two additional series of probit-regressions on firms' investment and innovation characteristics with the same vector of controls. The first includes the additive index of redistributive threats but excludes institutional proxies. The second, on the contrary, includes institutional variables but excluding the additive index. In the first series results obtained for the risk indicators are almost identical to those in Tables 8 in terms of both the direction and the size of the effects. The only difference is that the effect of the additive index on probability for the firm to have investment projects, although staying negative, ceases to be statistically significant. In the second series the results are also not substantially different from those in Table 8 either. In most cases regression coefficients for institutional variables remain insignificant and frequently enter the estimated equations with a positive sign. The differences worth mentioning are that the effect on innovations of perceived inability of courts to provide judicial protection against the state ceases to be significant whilst the effect

${ }^{12}$ Another plausible interpretation is that firms more prone to tax evasion have more effective and sophisticated accounting departments. A proverb very popular in Russian business in the 90-s says: "If your firm's accounts show profit it means that you have an inapt accountant". 
on future investment of lack of personal safety becomes significant at 0.05 level. Overall, findings for both the risk variables and institutional proxies prove to be robust to changes in model specifications (the results are available on request).

A possible problem with our findings is potential multicollinearity that could occur in the presence of high correlation between variables. However, for all estimated equations variance inflation factors stay in the narrow range of only 4.5-5.5 and thus are substantially below the levels that are considered to be critical in the econometrics literature (Kutner, 2004). This indicates that our estimates are not likely to be seriously affected by this problem.

Finally, it is necessary to consider the possibility that our results might be biased due to endogeneity in the form of reverse causality when the firm's investment and innovative activity determine the perception of redistributive threats held by its managers. Indeed, it is not illogical to assume that of two firms identical in terms of structural, ownership and performance-related characteristics the more investing and innovative one would be a more attractive target for potential assailant than less investing and less innovative one. Hence, if in the case of direct causality we can expect a negative association between threats of asset seizure and firm's investment and innovative activity, in the case of reverse causality it should be positive. In fact, our estimations produce negative association thus implying that direct causality dominates over the reverse one. From this we can infer that, if the effects of endogeneity are abstracted away, the true impact of redistributive threats on firms' investment and innovative activity would remain negative, but even larger by size than those presented in Tables 8 or 9 . However, it must be acknowledged that our data are not panel and 
there are no good instruments for our redistributive risks in it. Therefore, our findings are not sufficient to make strong causal claims and should be interpreted with caution.

\section{Conclusions}

Our study contributes to the literature by employing a new approach to measuring the security of property rights and the evaluation of their impact on firms' performance. Although our analysis focuses on Russia, as far as the application of the new metrics is concerned, it is of general relevance. Our research broadly supports the existing view of a close relationship between institutions, property rights and economic growth, it suggests that the ability of some of the widely used measures of the insecurity of property rights to come to grips with the "strategic" risks of asset seizure is limited. This study has own limitations of course. The fact that our research is based on cross-section data restricts our ability to make strong causal claims. Another issue is that our measures reflect personal perceptions of the respondents. There is a debate in literature regarding the extent to which perceptions data, despite many advantages, adequately capture the relevant reality. A prevailing view seems to be, however, that any possible concerns cannot disqualify the use of such data (Kaufman et al 2007, 2010).

The measures introduced in this paper complement traditional measures. They help to operationalize the problem of the insecurity of property rights and enrich our understanding of this phenomenon. Our analysis shows that the risk indices that we have identified reflect profound behavioural traits and have a strong and significant impact on various indicators of investment and innovative activity. In this sense the new metrics that we have proposed in 
this paper contributes to a more complete picture of the negative influence of the insecure property rights on firms' long-term economic decisions.

On the whole this study confirms that the Russian economy continues to operate on extremely shaky foundations as far as the status of property rights is concerned. Under such circumstances it is difficult to expect high levels of investment and innovation activity, because the owners see their chances to receive any benefit from long-term projects as extremely problematic. At the same time it must be remembered that our research is based on data collected during an acute phase of a deep economic recession when most surveyed companies experienced a sharp deterioration in economic performance. It is plausible that if the survey had been conducted in a different environment some of responses could have been less pessimistic. We tried to minimise the impact of economic conjuncture by introducing a distinction between "market" and "non-market" risks of property redistribution and excluding "the risk of bankruptcy" from our analysis. Overall, we believe that the survey has succeeded in revealing some fundamental attitudes that do not depend on the phase of the economic cycle.

Our findings have general implications for other transition economies and developing economies. They confirm that redistributive risks provide a depressing effect on investment and innovative activity of manufacturing enterprises and potentially result in a huge loss in efficiency and economic growth, which in other institutional settings could have been avoided. This result suggests that an increase in the security of property rights remains an important resource that can substantially improve the perspectives of economic growth in these countries. 
7. Acknowledgements

\section{References}

Aidis, Ruta, Estrin, Saul, Mickiewicz, Tomasz, 2009. Entrepreneurial entry: which institutions matter? Institute for the Study of Labour IZA Discussion Paper No. 4123, Bonn, Germany.

Asoni, Andrea, 2008. Protection of property rights and growth as political equilibria. IFN Working Paper No. 737.

Besley, Timothy, Ghatak, Maitreesh, 2009. Property rights and economic development. In Rodrick, Dani and Rosenzweig, Mark, (eds.) Handbook of development economics. Elsevier, pp. $4525-4595$.

BEEPS, 1999. Business Environment and Enterprise Performance Survey, EBRD/World Bank.

Chernykh, Lucy, 2009. Profit or Politics? Understanding Renationalizations in Russia. Available at SSRN: http://ssrn.com/abstract $=1562047$

Clarke, George R. G., 2001. How institutional quality and economic factors impact technological deepening in developing countries. Journal of International Development 13, $1097-1118$.

Cameron, Colin A., Trivedi, Pravin K., 1986. Econometric models based on count data: comparisons and applications of some estimators and tests. Journal of Applied Econometrics, 1, 29-53.

Dincer, Oguzhan, 2007. The effects of property rights on economic performance. Applied Economics, 39, 825-837. 
Dzarasov, Ruslan, 2011. Eichnerian megacorp and investment behaviour of Russian corporations. Cambridge Journal of Economics, 35, 199-217.

Easterbrook, Frank H., Fischel, Daniel R., 1991. The Economic Structure of Corporate Law. Cambridge, Mass., Harvard University Press, 370 pp.

EBRD, 2010. EBRD Insolvency Law Assessment Project, 2009: Russian Federation. Country report. London, EBRD.

Firestone, Thomas, 2008. Criminal corporate raiding in Russia. The International Lawyer, 42, 1207-1229.

Firestone, Thomas, 2010. Abuse of the law and complex crime in post-Soviet Russia. Denver Journal of International Law \& Policy, 38, 555-580.

Freeland, Chrystia, 2000. Sale of the Century: Russia's Wild Ride from Communism to Capitalism. New York, Random House.

Frye, Timothy, 2002. Private protection in Russia and Poland. American Journal of Political Science, 46, 572-584.

Frye, Timothy, 2004. Credible commitment and property rights: evidence from Russia. American Political Science Review, 98, 453-466.

Frye, Timothy, 2006. Original sin, good works and property rights in Russia. World Politics, $58,479-504$.

Goriaev, Alexei, Sonin, Konstantin, 2005. Is political risk company-specific? The market side of the Yukos affair. EFA 2005 Moscow Meetings. Available at SSRN: http://ssrn.com/abstract=676875 or doi:10.2139/ssrn.676875. 
Hartarska, Valentina, 2001. Investments and Property Rights in Russia: Evidence from Small Firms in Russia. Paper presented at annual meeting of the American Agricultural Economics Association, Chicago, 2001.

Hellman, Joel S., Jones, Geraint, Kaufmann, Daniel, 2000. "Seize the state, seize the day": state capture, corruption, and influence in transition. Policy Research Working Paper Series 2444, Washington, The World Bank.

Hellman, Joel, Kaufmann, Daniel, 2002. The Inequality of Influence. Working paper of the World Bank Institute, Washington Ac. Available at http://siteresources.worldbank.org/INTWBIGOVANTCOR/Resources/inequality_influence.p df

Hendley, Kathryn, Murrell, Peter, Ryterman, Randi, 2000. Law, relationships and private enforcement: transactional strategies of Russian enterprises. Europe-Asia Studies, 52, 627656.

Hoff, Karla, Stiglitz, Joseph E., 2002. After the big bang? Obstacles to the emergence of the rule of law in post-communist societies. National Bureau of Economic Research Working Paper 9282. Available at http://www.nber.org/papers/w9282

Johnson, Simon, McMillan, John, Woodruff, Christopher, 2002. Property rights and finance. American Economic Review, 92, 1335-56.

Kaufmann, Daniel, Kraay, Aart, Mastruzzi, Massimo, 2007. Growth and governance: a reply/rejoinder. Journal of Politics. 69, 555-562.

Kaufmann, Daniel, Kraay, Aart, Mastruzzi, Massimo, 2010. The worldwide governance indicators: methodology and analytical issues. World Bank, Washington DC. 
Knack, Stephen, Keefer, Phillip, 1995. Institutions and economic performance: cross-country tests using alternative institutional measures. Economics and Politics, 7, 207-27.

Kornai, János, 2000. Making the transition to private ownership. Finance \& Development, 37(3). Available at http://www.imf.org/external/pubs/ft/fandd/2000/09/kornai.htm

Kutner, Michael, Nachtsheim, Christopher, Neter, John, 2004. Applied Linear Regression Models, 4th edition, McGraw-Hill Irwin.

Kuznetsov, Andrei, Kapelyushnikov, Rostislav, Dyomina, Natalya, 2008. Performance of closely held firms in Russia: evidence from firm-level data. The European Journal of Finance, 14, 337-358.

Lazareva, Olga, Rachinsky, Andrei, Stepano, Sergey, 2007. A survey of corporate governance in Russia. Working Paper No 103, CEFIR / NES.

Mauro, Paolo, 1995. Corruption and growth. Quarterly Journal of Economics, 70, pp. 681712.

Moran, Michael, 2001. The lost legitimacy: property, business power and the constitution. Public Administration, 79, 277-296.

Olson, Mancur, 1982. The Rise and Decline of Nations: Economic Growth, Stagflation andEconomic Rigidities. New Haven, USA, and London, UK: Yale University Press.

Olson, Mancur, 1996. Big bills left on the sidewalk: Why some nations are rich, and others are poor. Journal of Economic Perspectives, 10: 3-24.

Osipian, Ararat L., 2010. Corporate raiding Russian style: hostile takeovers via corruption and fraud. Paper presented at the Annual Conference of the American Political Science Association (APSA), Washington, DC, in September 2010. 
Polishchuk Leonid, Savvateev, Alexei, 2004. Spontaneous (non)emergence of property rights. Economics of Transition, 12, 103-127.

Pyle, William, 2007. Organized business, political regimes and property rights across the Russian Federation. BOFIT Discussion Paper No. 18, Helsinki, Finland.

Radygin, A. 2009. Vnutrennie mekhanizmy korporativnogo upravlenia. Moscow: Delo.

Roland, Gérard, Verdie, Thierry, 2003. Law enforcement and transition. European Economic Review, 47, 669-68.

Shleifer, Andrei, 1997. Government in transition. European Economic Review, 41, 385-410.

Shleifer, Andrei, Treisman, Daniel, 2001. Without a map: political tactics and economic reform in Russia. MIT Press: Cambridge.

Sonin, Konstantin, 2003. Why the rich may favor poor protection of property rights. Journal of Comparative Economics, 31, 715-731.

Stubbs, Tim, 2009. Overview of Russian bankruptcy law and practice: what can creditors expect in the current crisis? Presentation for the US-Russia Business Council. Available at https://www.usrbc.org/pics/File/Events/LegalConference2009/Tim\%20Stubbs\%20Bankruptc y\%20Law\%20presentation_Eng_final.pdf

Yasin, Yevgeny, Gimpelson, Vladimir, Golikova, Victoria, Gonchar, Ksenia., Dolgopyatova, Tatiana, Kuznetsov, Boris, Yakovlev, Andrei. 2010. Russian manufacturing revisited: industrial enterprises at the start of the 2008 financial crisis. Helsinki: 2010. BOFIT Online No. 5 .

Zhang, Xin, 2008. The end of "primitive accumulation"? Political economy of bankruptcy legislations in Russia. Paper presented at the annual meeting of the MPSA Annual National Conference, Chicago, Il. 
Zhuravskaya, Elena, (2008) Is there the rule of law in Russia? The case of corporate raiding:

a note. Economics Working Paper No.94, Centre for Research into Post-Communist Economies, UCL, London.

Table 1 Perceived probability of threats to property rights by type, percent

\begin{tabular}{|l|c|c|c|c|c|}
\hline $\begin{array}{l}\text { How probable is it that in the next 2 or 3 } \\
\text { years your firm... }\end{array}$ & $\begin{array}{c}\text { Very } \\
\text { probable }\end{array}$ & $\begin{array}{c}\text { More or less } \\
\text { probable }\end{array}$ & $\begin{array}{c}\text { Very } \\
\text { improbable }\end{array}$ & Total & N \\
\hline $\begin{array}{l}\text { will be included into a state-owned } \\
\text { company }\end{array}$ & 8.9 & 36.5 & 54.6 & 100 & 866 \\
\hline $\begin{array}{l}\text { will be taken over by a larger and more } \\
\text { powerful private company }\end{array}$ & 13.6 & 47.6 & 38.8 & 100 & 863 \\
\hline will be subjected by raiders attacks & 14.0 & 47.3 & 38.7 & 100 & 850 \\
\hline $\begin{array}{l}\text { will fall under control of local/regional } \\
\text { authorities }\end{array}$ & 12.0 & 46.2 & 41.8 & 100 & 844 \\
\hline $\begin{array}{l}\text { will suffer from inter-corporate conflicts } \\
\text { among major shareholders }\end{array}$ & 7.3 & 40.7 & 52.0 & 100 & 865 \\
\hline
\end{tabular}

Table 2 Distribution of the surveyed firms by the number of responses "very probable", "more or less probable" and "very improbable" to the question on anticipated redistributive threats, percent

\begin{tabular}{|l|c|c|c|}
\hline Number of anticipated threats & Very probable & More or less probable & Very improbable \\
\hline 0 & 64.7 & 23.1 & 20.7 \\
\hline 1 & 23.3 & 15.9 & 16.3 \\
\hline 2 & 8.7 & 18.1 & 14.5 \\
\hline 3 & 2.1 & 16.5 & 10.8 \\
\hline 4 & 0.7 & 13.3 & 17.5 \\
\hline 5 & 0.5 & 13.2 & 2.27 \\
\hline $\begin{array}{l}\text { Average number of anticipated } \\
\text { threats (out of possible five) by } \\
\text { probability per company }\end{array}$ & 0.52 & 2.21 & \\
\hline
\end{tabular}


Table 3 Correlation matrix of redistributive threats (Spearman's rho)

\begin{tabular}{|l|c|c|c|c|c|}
\hline $\begin{array}{l}\text { How probable is it that in the next } 2 \text { or } 3 \text { years } \\
\text { your firm... }\end{array}$ & 1 & 2 & 3 & 4 & 5 \\
\hline $\begin{array}{l}\text { 1. will be included into a state-owned company } \\
\text { 2. will be taken over by a larger and more } \\
\text { powerful private company }\end{array}$ & $0.323^{* * *}$ & 1 & $0.408^{* *}$ & $0.372^{* * *}$ & $0.325^{* * *}$ \\
\hline \begin{tabular}{l} 
3. will be subjected by raiders attacks \\
\hline $\begin{array}{l}\text { 4. will fall under control of local/regional } \\
\text { authorities }\end{array}$
\end{tabular} & $0.320^{* * *}$ & $0.372^{* * *}$ & $0.416^{* * *}$ & 1 & $0.340^{* * *}$ \\
\hline $\begin{array}{l}\text { 5. will be suffered from inter-corporate conflicts } \\
\text { among major shareholders }\end{array}$ & $0.263^{* * *}$ & $0.325^{* * *}$ & $0.374^{* * *}$ & $0.340^{* * *}$ & 1 \\
\hline
\end{tabular}

Notes: include firms that gave estimates for all five positions; ${ }^{* *} \rho \geq 0.01$ (two tail). 
Table 4 Redistributive threats as confronted by various categories of firms

\begin{tabular}{|c|c|c|c|c|c|c|}
\hline \multirow[t]{2}{*}{ Categories } & \multicolumn{5}{|c|}{ Share of firms (\%) perceiving as "very probable" } & \multirow{2}{*}{$\begin{array}{c}\text { Average } \\
\text { number of } \\
\text { "very } \\
\text { probable" } \\
\text { threats per } \\
\text { firm }\end{array}$} \\
\hline & $\begin{array}{l}\text { inclusion } \\
\text { into a } \\
\text { state- } \\
\text { owned } \\
\text { company }\end{array}$ & $\begin{array}{c}\text { take-over by } \\
\text { a larger } \\
\text { private } \\
\text { company }\end{array}$ & $\begin{array}{l}\text { raiders } \\
\text { attacks }\end{array}$ & $\begin{array}{l}\text { falling under } \\
\text { control of } \\
\text { local/ } \\
\text { regional } \\
\text { authorities }\end{array}$ & \begin{tabular}{|c|} 
inter- \\
corporate \\
conflicts \\
among major \\
shareholders
\end{tabular} & \\
\hline \multicolumn{7}{|c|}{ Size (number of employees) } \\
\hline Less than 100 & 4.2 & 17.9 & 18.1 & 12.3 & 9.0 & 0.62 \\
\hline $100-250$ & 6.0 & 15.8 & 16.3 & 14.7 & 7.8 & 0.61 \\
\hline $251-500$ & 7.1 & 12.0 & 12.5 & 11.7 & 8.3 & 0.52 \\
\hline $501-1000$ & 10.5 & 11.6 & 12.8 & 7.9 & 7.7 & 0.51 \\
\hline More than 1000 & 20.8 & 9.5 & 9.5 & 11.0 & 2.4 & 0.53 \\
\hline \multicolumn{7}{|l|}{ Location } \\
\hline Moscow & 18.2 & 7.1 & 22.2 & 9.6 & 7.1 & 0.64 \\
\hline Large city & 10.6 & 9.8 & 13.6 & 10.2 & 5.9 & 0.50 \\
\hline Small town & 6.5 & 18.0 & 11.5 & 13.9 & 9.1 & 0.59 \\
\hline Countryside & 3.2 & 18.8 & 22.4 & 13.6 & 6.3 & 0.64 \\
\hline \multicolumn{7}{|l|}{ Age } \\
\hline Founded before 1992 & 10.4 & 14.2 & 14.4 & 12.4 & 7.9 & 0.59 \\
\hline Founded in 1992 or later & 4.5 & 11.8 & 13.0 & 10.6 & 5.5 & 0.45 \\
\hline \multicolumn{7}{|l|}{ State ownership } \\
\hline No & 5.1 & 13.1 & 15.0 & 10.5 & 7.8 & 0.52 \\
\hline Yes & 40.8 & 22.2 & 11.5 & 21.1 & 7.2 & 1.03 \\
\hline \multicolumn{7}{|l|}{ Foreign ownership } \\
\hline No & 7.1 & 14.8 & 16.0 & 11.4 & 7.6 & 0.57 \\
\hline Yes & 3.9 & 8.1 & 6.9 & 7.8 & 8.2 & 0.35 \\
\hline \multicolumn{7}{|c|}{ Insider (managerial) ownership } \\
\hline No & 6.2 & 11.8 & 17.4 & 11.4 & 7.8 & 0.55 \\
\hline Yes & 8.0 & 15.2 & 8.9 & 11.4 & 6.1 & 0.50 \\
\hline
\end{tabular}




\begin{tabular}{|c|c|c|c|c|c|c|}
\hline \multicolumn{7}{|c|}{ Degree of market competition } \\
\hline Low & 8.1 & 9.6 & 12.0 & 10.2 & 4.1 & 0.44 \\
\hline High & 9.1 & 14.7 & 14.5 & 12.5 & 8.2 & 0.59 \\
\hline \multicolumn{7}{|c|}{ Sales for export } \\
\hline No & 9.4 & 15.9 & 13.7 & 16.4 & 7.3 & 0.63 \\
\hline Yes & 8.5 & 11.7 & 14.3 & 8.5 & 6.6 & 0.49 \\
\hline \multicolumn{7}{|c|}{ Financial condition } \\
\hline Poor & 7.2 & 26.2 & 17.4 & 13.0 & 8.8 & 0.73 \\
\hline Satisfactory & 10.3 & 12.1 & 13.4 & 13.7 & 7.0 & 0.57 \\
\hline Good & 6.0 & 8.1 & 13.1 & 6.4 & 7.0 & 0.41 \\
\hline \multicolumn{7}{|c|}{ Subsidies from the federal budget } \\
\hline No & 8.1 & 13.8 & 14.3 & 11.8 & 7.4 & 0.55 \\
\hline Yes & 15.6 & 12.0 & 12.0 & 12.1 & 6.7 & 0.58 \\
\hline \multicolumn{7}{|c|}{$\begin{array}{l}\text { Subsidies from the local/regional } \\
\text { budgets }\end{array}$} \\
\hline No & 8.4 & 13.5 & 13.3 & 10.1 & 7.0 & 0.52 \\
\hline Yes & 11.2 & 13.7 & 17.2 & 20.0 & 8.6 & 0.71 \\
\hline \multicolumn{7}{|c|}{$\begin{array}{l}\text { Financing social projects run by } \\
\text { regional or local authorities }\end{array}$} \\
\hline No & 8.2 & 12.7 & 6.8 & 7.3 & 4.0 & 0.39 \\
\hline Yes & 9.1 & 13.8 & 16.1 & 13.4 & 8.3 & 0.61 \\
\hline \multicolumn{7}{|c|}{ Recent litigation experience } \\
\hline No & 7.1 & 10.4 & 10.3 & 12.6 & 6.5 & 0.47 \\
\hline Yes & 9.5 & 14.6 & 15.2 & 11.8 & 7.6 & 0.59 \\
\hline \multicolumn{7}{|c|}{$\begin{array}{l}\text { Confidence in judicial protection in } \\
\text { disputes with other firms }\end{array}$} \\
\hline No & 10.0 & 11.8 & 12.1 & 13.2 & 6.9 & 0.54 \\
\hline Yes & 5.5 & 16.4 & 17.3 & 8.3 & 8.8 & 0.56 \\
\hline $\begin{array}{l}\text { Confidence } \\
\text { disputes wi }\end{array}$ & & & & & & \\
\hline
\end{tabular}




\begin{tabular}{|l|c|c|c|c|c|c|}
\hline No & 8.2 & 11.2 & 7.9 & 11.6 & 5.7 & 0.45 \\
\hline Yes & 8.9 & 15.1 & 19.9 & 12.8 & 0.46 \\
\hline Engagement in tax evasion & & & & & \\
\hline No & 10.1 & 13.0 & 12.9 & 10.9 & 5.8 & 0.53 \\
\hline Yes & 7.6 & 14.2 & 15.2 & 13.1 & 8.8 & 0.59 \\
\hline Corruption as obstacle & & & & & \\
\hline Not important & 8.9 & 10.9 & 9.0 & 10.1 & 5.7 & 0.45 \\
\hline Important & 8.8 & 17.5 & 21.3 & 14.7 & 9.7 & 0.72 \\
\hline Lack of safety as obstacle & & & & & \\
\hline Not important & 8.8 & 11.3 & 10.0 & 10.5 & 5.8 \\
\hline Important & & 23.5 & 31.1 & 18.2 & 13.4 \\
\hline
\end{tabular}


Table 5 Probit regressions for specific redistributive threats (marginal effects)

\begin{tabular}{|c|c|c|c|c|c|}
\hline & $\begin{array}{c}\text { Inclusion into } \\
\text { a state- } \\
\text { owned } \\
\text { company }\end{array}$ & $\begin{array}{l}\text { Take-over by } \\
\text { a larger } \\
\text { private } \\
\text { company }\end{array}$ & $\begin{array}{l}\text { Raiders } \\
\text { attacks }\end{array}$ & $\begin{array}{l}\text { Falling under } \\
\text { control of } \\
\text { local/ } \\
\text { regional } \\
\text { authorities }\end{array}$ & \begin{tabular}{|c|} 
Inter- \\
corporate \\
conflicts \\
among major \\
share-holders
\end{tabular} \\
\hline \multirow[t]{2}{*}{ State ownership (yes $=1$ ) } & 0.19 & 0.21 & -0.04 & 0.16 & -0.02 \\
\hline & $(5.09)^{* * *}$ & $(3.25)^{* * *}$ & $(0.85)$ & $(2.82)^{* *}$ & $(0.87)$ \\
\hline \multirow[t]{2}{*}{ Foreign ownership (yes = 1) } & -0.01 & -0.03 & -0.04 & -0.01 & 0.01 \\
\hline & $(0.75)$ & $(0.92)$ & $(1.30)$ & $(0.34)$ & $(0.47)$ \\
\hline \multirow[t]{2}{*}{ Insider (managerial) ownership (yes $=1$ ) } & 0.02 & -0.02 & 0.06 & 0.02 & 0.01 \\
\hline & $(1.76)^{*}$ & (0.98) & $(2.55)^{* *}$ & $(1.12)$ & $(0.45)$ \\
\hline \multirow[t]{2}{*}{ Financial condition $($ poor $=1)$} & -0.00 & 0.11 & 0.04 & 0.03 & 0.01 \\
\hline & $(0.30)$ & $(3.01)^{* * *}$ & $(1.39)$ & $(0.92)$ & $(0.35)$ \\
\hline \multirow[t]{2}{*}{ Ln number of employees } & 0.02 & -0.02 & -0.03 & -0.01 & -0.02 \\
\hline & $(3.41)^{* * *}$ & (1.18) & $(2.45)^{* *}$ & $(0.94)$ & $(2.34)^{* *}$ \\
\hline \multirow[t]{2}{*}{ Market competition (high = 1) } & 0.01 & 0.06 & 0.01 & 0.01 & 0.01 \\
\hline & $(0.69)$ & $(2.28)^{* *}$ & $(0.39)$ & $(0.81)$ & $(0.77)$ \\
\hline \multirow[t]{2}{*}{ Sales for export (yes $=1$ ) } & -0.06 & -0.05 & 0.08 & -0.05 & 0.03 \\
\hline & $(4.21)^{* * *}$ & $(1.95)^{*}$ & $(0.43)$ & $(1.95)^{*}$ & $(1.41)$ \\
\hline \multirow{2}{*}{$\begin{array}{l}\text { Financial aid from the federal authorities } \\
\text { (yes = 1) }\end{array}$} & 0.03 & -0.00 & -0.01 & -0.02 & -0.00 \\
\hline & $(1.51)$ & $(0.00)$ & $(0.30)$ & $(0.65)$ & $(0.18)$ \\
\hline \multirow{2}{*}{$\begin{array}{l}\text { Financial aid from regional or local } \\
\text { authorities (yes }=1 \text { ) }\end{array}$} & -0.01 & -0.03 & 0.03 & 0.07 & 0.01 \\
\hline & $(0.43)$ & $(0.88)$ & $(0.86)$ & $(1.93)^{* *}$ & $(0.70)$ \\
\hline \multirow{2}{*}{$\begin{array}{l}\text { Financing social projects run by regional } \\
\text { or local authorities (yes }=1 \text { ) }\end{array}$} & -0.01 & 0.02 & 0.08 & 0.03 & 0.05 \\
\hline & $(0.54)$ & $(0.49)$ & $(2.83)^{* * *}$ & $(1.29)$ & $(2.55)^{* *}$ \\
\hline \multirow[t]{2}{*}{ Recent litigation experience (yes $=1$ ) } & 0.02 & 0.04 & 0.04 & 0.02 & 0.01 \\
\hline & $(1.85)^{* *}$ & $(1.21)$ & $(1.40)$ & $(0.92)$ & $(0.26)$ \\
\hline \multirow{2}{*}{$\begin{array}{l}\text { Confidence in judicial protection in } \\
\text { disputes with other firms (no }=1 \text { ) }\end{array}$} & -0.02 & 0.03 & -0.02 & -0.06 & 0.01 \\
\hline & $(2.04)^{* *}$ & $0.95)$ & $(1.00)$ & $(2.78)^{* * *}$ & $(0.43)$ \\
\hline
\end{tabular}




\begin{tabular}{|l|c|c|c|c|c|}
\hline \multirow{2}{*}{$\begin{array}{l}\text { Confidence in judicial protection in } \\
\text { disputes with state (no = 1) }\end{array}$} & 0.01 & 0.01 & $\mathbf{0 . 0 9}$ & 0.00 & 0.01 \\
\cline { 2 - 6 } & $(0.97)$ & $(0.36)$ & $\mathbf{( 3 . 7 7 ) ^ { * * * }}$ & $(0.07)$ & $(0.83)$ \\
\hline Engagement in tax evasion (yes = 1) & 0.01 & 0.02 & 0.02 & 0.02 & $\mathbf{0 . 0 5}$ \\
\cline { 2 - 6 } & $(0.62)$ & $(0.55)$ & $(0.96)$ & $(0.98)$ & $\mathbf{( 3 . 1 1 ) ^ { * * * }}$ \\
\hline Corruption as obstacle (important = 1) & -0.00 & 0.02 & $\mathbf{0 . 0 4}$ & $\mathbf{0 . 0 4}$ & 0.01 \\
\cline { 2 - 6 } & $(0.04)$ & $(0.72)$ & $\mathbf{( 1 . 7 4 ) ^ { * }}$ & $\mathbf{( 1 . 6 6 ) ^ { * }}$ & $(0.30)$ \\
\hline Lack of safety as obstacle (important = 1) & $\mathbf{0 . 0 2}$ & $\mathbf{0 . 0 6}$ & $\mathbf{0 . 1 4}$ & $\mathbf{0 . 0 6}$ & $\mathbf{0 . 0 4}$ \\
\cline { 2 - 6 } & $\mathbf{( 1 . 8 4 ) ^ { * }}$ & $\mathbf{( 1 . 7 9 ) ^ { * }}$ & $\mathbf{( 4 . 1 4 ) ^ { * * * }}$ & $\mathbf{( 2 . 0 6 ) ^ { * * }}$ & $\mathbf{( 2 . 0 1 ) ^ { * * }}$ \\
\hline Age (founded in 1992 or later = 1) & -0.01 & -0.01 & 0.01 & 0.01 & -0.00 \\
\cline { 2 - 7 } & $(0.99)$ & $(0.26)$ & $(0.47)$ & $(0.22)$ & $(0.02)$ \\
\hline Location (countryside = 1) & -0.01 & 0.08 & $\mathbf{0 . 1 3}$ & 0.02 & -0.01 \\
\cline { 2 - 7 } & $(0.29)$ & $(1.35)$ & $\mathbf{( 2 . 3 6 ) ^ { * * }}$ & $(0.49)$ & $(0.33)$ \\
\hline Regions & included & included & included & included & included \\
\hline Industries & included & included & included & included & included \\
\hline Observations & 628 & 617 & 628 & 607 & 630 \\
\hline Pseudo R2 & 0.28 & 0.13 & 0.22 & 0.14 & 0.16 \\
\hline
\end{tabular}

Notes: ${ }^{*}$ significant at $0.1 * *$ significant at $0.05 * * *$ significant at 0.01 . Robust z-statistics in parentheses. 
Table 6 Regression estimates for the integral indices of the insecurity of property rights (marginal effects)

\begin{tabular}{|c|c|c|c|}
\hline & OLS (additive index) & $\begin{array}{l}\text { Negative binomial } \\
\text { regression (additive } \\
\text { index) }\end{array}$ & Probit (binary index) \\
\hline \multirow[t]{2}{*}{ State ownership (yes = 1) } & 0.54 & 0.44 & 0.38 \\
\hline & $(3.48)^{* * *}$ & $(2.86)^{* * *}$ & $(4.09)^{* * *}$ \\
\hline \multirow[t]{2}{*}{ Foreign ownership (yes = 1) } & -0.08 & -0.06 & -0.03 \\
\hline & $(0.87)$ & (0.69) & $(0.45)$ \\
\hline \multirow{2}{*}{$\begin{array}{l}\text { Insider (managerial) ownership (yes } \\
=1 \text { ) }\end{array}$} & 0.10 & 0.08 & 0.03 \\
\hline & (1.53) & $(1.62)$ & $(0.75)$ \\
\hline \multirow[t]{2}{*}{ Financial condition $($ poor $=1$ ) } & 0.19 & 0.13 & 0.11 \\
\hline & $(1.80)^{*}$ & $(1.81)^{*}$ & $(1.89)^{*}$ \\
\hline \multirow[t]{2}{*}{ Ln number of employees } & -0.07 & -0.06 & -0.04 \\
\hline & $(1.81)^{*}$ & $(2.00)^{* *}$ & $(1.86)^{*}$ \\
\hline \multirow[t]{2}{*}{ Market competition (high $=1$ ) } & 0.16 & 0.16 & 0.11 \\
\hline & $(2.21)^{* *}$ & $(2.73)^{* * *}$ & $(2.15)^{* *}$ \\
\hline \multirow[t]{2}{*}{ Sales for export (yes $=1$ ) } & -0.09 & -0.09 & -0.07 \\
\hline & $(1.20)$ & $(1.36)$ & $(1.51)$ \\
\hline \multirow{2}{*}{$\begin{array}{l}\text { Financial aid from the federal } \\
\text { authorities (yes }=1 \text { ) }\end{array}$} & 0.02 & 0.01 & -0.07 \\
\hline & $(0.20)$ & $(0.10)$ & $(0.28)$ \\
\hline \multirow{2}{*}{$\begin{array}{l}\text { Financial aid from regional or local } \\
\text { authorities (yes }=1 \text { ) }\end{array}$} & 0.05 & 0.07 & 0.11 \\
\hline & $(0.55)$ & $(0.92)$ & $(1.66)^{*}$ \\
\hline \multirow{2}{*}{$\begin{array}{l}\text { Financing social projects run by } \\
\text { regional or local authorities (yes }=1 \text { ) }\end{array}$} & 0.17 & 0.14 & 0.12 \\
\hline & $(2.02) * *$ & $(2.09) * *$ & $(2.19) * *$ \\
\hline \multirow[t]{2}{*}{ Recent litigation experience (yes $=1$ ) } & 0.15 & 0.12 & 0.15 \\
\hline & $(1.83)^{*}$ & $(1.95)^{* *}$ & $(3.05)^{* * *}$ \\
\hline \multirow{2}{*}{$\begin{array}{l}\text { Confidence in judicial protection in } \\
\text { disputes with other firms }(\text { no }=1)\end{array}$} & -0.10 & -0.07 & -0.07 \\
\hline & $(1.22)$ & $(1.36)$ & (1.45) \\
\hline
\end{tabular}




\begin{tabular}{|c|c|c|c|}
\hline \multirow{2}{*}{$\begin{array}{l}\text { Confidence in judicial protection in } \\
\text { disputes with state }(\text { no }=1)\end{array}$} & 0.12 & 0.09 & 0.09 \\
\hline & $(1.66)^{*}$ & $(1.72)^{*}$ & $(1.92)^{*}$ \\
\hline \multirow[t]{2}{*}{ Engagement in tax evasion (yes $=1$ ) } & 0.14 & 0.11 & 0.04 \\
\hline & $(1.95)^{* *}$ & $(2.05)^{* *}$ & $(0.91)$ \\
\hline \multirow{2}{*}{$\begin{array}{l}\text { Corruption as obstacle (important }= \\
\text { 1) }\end{array}$} & 0.16 & 0.11 & 0.06 \\
\hline & $(2.07)^{* *}$ & $(1.88)^{*}$ & $(1.34)$ \\
\hline \multirow{2}{*}{$\begin{array}{l}\text { Lack of safety as obstacle (important } \\
=1 \text { ) }\end{array}$} & 0.37 & 0.26 & 0.22 \\
\hline & $(3.48)^{* * *}$ & $(3.02)^{* * *}$ & $(4.07)^{* * *}$ \\
\hline \multirow[t]{2}{*}{ Age (founded in 1992 or later $=1$ ) } & -0.04 & -0.04 & 0.02 \\
\hline & $(0.62)$ & $(0.75)$ & $(0.50)$ \\
\hline \multirow[t]{2}{*}{ Location $($ countryside $=1$ ) } & 0.22 & 0.20 & 0.21 \\
\hline & $(1.72)^{*}$ & $(1.73)^{*}$ & $(2.41)^{* *}$ \\
\hline Regions & included & included & included \\
\hline Industries & included & included & included \\
\hline $\mathrm{N}$ of observations & 581 & 581 & 642 \\
\hline Adj. R2 or Pseudo R2 & 0.19 & 0.14 & 0.15 \\
\hline
\end{tabular}

Notes: ${ }^{*}$ significant at $0.1{ }^{* *}$ significant at $0.05^{* * *}$ significant at 0.01 . Robust t-statistics or $\mathrm{z}$ statistics in parentheses. 
Table 7 Probit regressions for the characteristics of firms' investment and innovation behavior (specifications with specific redistributive risks, marginal effects)*

\begin{tabular}{|c|c|c|c|c|c|}
\hline Regressions & $\begin{array}{c}\text { Large } \\
\text { investments }\end{array}$ & Innovations & $\begin{array}{l}\text { Provision of } \\
\text { customer } \\
\text { credit }\end{array}$ & $\begin{array}{l}\text { Investment } \\
\text { projects for } \\
\text { the next year }\end{array}$ & $\begin{array}{l}\text { Use of long- } \\
\text { term strategic } \\
\text { planning }\end{array}$ \\
\hline \multirow{3}{*}{$\begin{array}{l}\text { Inclusion into a state-owned } \\
\text { company }\end{array}$} & -0.10 & -0.04 & -0.22 & -0.15 & -0.01 \\
\hline & (1.47) & $(0.56)$ & $(2.54)^{* *}$ & $(1.84)^{*}$ & $(0.12)$ \\
\hline & 633 & 634 & 625 & 608 & 534 \\
\hline $\mathrm{N}$ of observations & \multicolumn{4}{|c|}{ Pseudo R2 } & 0.26 \\
\hline \multirow{3}{*}{$\begin{array}{l}\text { Take-over by a larger private } \\
\text { company }\end{array}$} & -0.08 & -0.12 & -0.04 & -0.05 & -0.10 \\
\hline & (1.44) & $(2.17)^{*}$ & (0.69) & $(0.84)$ & $(1.81)^{*}$ \\
\hline & 622 & 623 & 617 & 598 & 526 \\
\hline $\mathrm{N}$ of observations & 0.12 & 0.25 & 0.15 & 0.12 & 0.25 \\
\hline \multirow[t]{3}{*}{ Raiders attacks } & -0.09 & 0.05 & -0.09 & -0.07 & 0.01 \\
\hline & (1.61) & $(0.80)$ & (1.50) & (1.19) & (0.23) \\
\hline & 633 & 634 & 625 & 608 & 534 \\
\hline $\mathrm{N}$ of observations & \multicolumn{5}{|c|}{ Pseudo R2 } \\
\hline \multirow{4}{*}{$\begin{array}{l}\text { Falling under control of local/ } \\
\text { regional authorities }\end{array}$} & -0.10 & -0.10 & -0.06 & -0.12 & -0.07 \\
\hline & (1.71)* & (1.46) & (0.92) & (1.76)* & (1.12) \\
\hline & 612 & 613 & 606 & 586 & 517 \\
\hline & \multicolumn{4}{|c|}{ Pseudo R2 } & 0.26 \\
\hline \multirow{4}{*}{$\begin{array}{l}\text { Inter-corporate conflicts among } \\
\text { major share-holders }\end{array}$} & -0.07 & -0.13 & -0.15 & -0.16 & -0.15 \\
\hline & (1.07) & $(2.19)^{*}$ & $(1.88)^{*}$ & $(2.17)^{*}$ & $(2.41)^{*}$ \\
\hline & 641 & 642 & 633 & 615 & 541 \\
\hline & 0.12 & 0.24 & 0.15 & 0.13 & 0.26 \\
\hline
\end{tabular}

* In addition to variables for specific redistributive threats all regressions include the following set of controls: state ownership; foreign ownership; insider (managerial) 
ownership; In number of employees; financial condition; market competition; sales for export; financial aid from the federal authorities; financial aid from regional or local authorities; financing social projects run by regional or local authorities; recent litigation experience; confidence in judicial protection in disputes with other firms; confidence in judicial protection in disputes with state; engagement in tax evasion; corruption; lack of safety; age; type of location; dummies for regions; dummies for sectors. 
Table 8 Probit regressions for the characteristics of firms' investment and innovation behavior (specification with the additive index of the insecurity of property rights, marginal effects)

\begin{tabular}{|c|c|c|c|c|c|}
\hline Variable & $\begin{array}{c}\text { Large } \\
\text { investments }\end{array}$ & Innovations & $\begin{array}{l}\text { Provision of } \\
\text { customer } \\
\text { credit }\end{array}$ & $\begin{array}{l}\text { Investment } \\
\text { projects for } \\
\text { the next year }\end{array}$ & $\begin{array}{c}\text { Use of long- } \\
\text { term } \\
\text { strategic } \\
\text { planning } \\
\end{array}$ \\
\hline \multirow{2}{*}{$\begin{array}{l}\text { Integral index of the insecurity of } \\
\text { property rights (additive) }\end{array}$} & -0.06 & -0.06 & -0.04 & -0.05 & -0.06 \\
\hline & $(2.41)^{* *}$ & $(2.39) * *$ & $(1.35)$ & $(1.96)^{*}$ & $(2.15)^{* *}$ \\
\hline \multirow[t]{2}{*}{ State ownership (yes $=1$ ) } & -0.06 & -0.07 & -0.24 & 0.03 & -0.07 \\
\hline & $(0.64)$ & $(0.91)$ & $(2.72)^{* * * *}$ & $(0.40)$ & $(0.90)$ \\
\hline \multirow{2}{*}{ Foreign ownership (yes = 1) } & 0.04 & 0.05 & -0.10 & 0.02 & 0.03 \\
\hline & $(0.64)$ & $(0.82)$ & $(1.50)$ & $(0.26)$ & $(0.47)$ \\
\hline \multirow{2}{*}{$\begin{array}{l}\text { Insider (managerial) ownership (yes = } \\
\text { 1) }\end{array}$} & -0.02 & 0.11 & -0.02 & -0.01 & 0.06 \\
\hline & $(0.51)$ & $(2.59)^{* *}$ & $(0.41)$ & $(0.18)$ & (1.36) \\
\hline \multirow{2}{*}{ Financial condition $($ poor $=1$ ) } & -0.10 & 0.05 & 0.02 & -0.11 & 0.05 \\
\hline & $(1.99)^{* *}$ & $(0.94)$ & $(0.45)$ & $(1.86) *$ & $(0.88)$ \\
\hline \multirow[t]{2}{*}{ Ln number of employees } & 0.08 & 0.10 & 0.05 & 0.04 & 0.09 \\
\hline & $(3.63)^{* * *}$ & $(4.59) * * *$ & $(2.25) * *$ & $(1.61)$ & $(3.75)^{* * * *}$ \\
\hline \multirow{2}{*}{ Market competition (high $=1$ ) } & -0.03 & 0.09 & 0.20 & -0.06 & 0.10 \\
\hline & $(0.64)$ & $(1.78)^{*}$ & $(3.75) * * *$ & $(1.02)$ & $(1.98) * *$ \\
\hline \multirow[t]{2}{*}{ Sales for export (yes $=1$ ) } & 0.01 & $\mathbf{0 . 2 0}$ & 0.03 & 0.02 & 0.19 \\
\hline & $(0.26)$ & $(4.08) * * *$ & $(0.71)$ & $(0.39)$ & $(3.64) * * *$ \\
\hline \multirow{2}{*}{$\begin{array}{l}\text { Financial aid from the federal } \\
\text { authorities (yes }=1 \text { ) }\end{array}$} & 0.05 & 0.17 & 0.05 & $\mathbf{0 . 2 3}$ & 0.13 \\
\hline & $(0.72)$ & $(2.14) * *$ & $(0.69)$ & $(\mathbf{2 . 7 0})^{* * *}$ & $(1.63)$ \\
\hline \multirow{2}{*}{$\begin{array}{l}\text { Financial aid from regional or local } \\
\text { authorities (yes }=1 \text { ) }\end{array}$} & 0.18 & -0.02 & 0.07 & -0.08 & 0.00 \\
\hline & $(3.11)^{* * *}$ & $(0.35)$ & $(1.27)$ & $(1.15)$ & $(0.02)$ \\
\hline \multirow{2}{*}{$\begin{array}{l}\text { Financing social projects run by } \\
\text { regional or local authorities (yes }=1 \text { ) }\end{array}$} & 0.10 & 0.06 & 0.03 & 0.05 & 0.06 \\
\hline & $(1.92)^{* *}$ & $(1.05)$ & $(0.49)$ & $(0.90)$ & (1.02) \\
\hline \multirow[t]{2}{*}{ Recent litigation experience (yes = 1) } & $\mathbf{0 . 1 2}$ & -0.02 & 0.05 & $\mathbf{0 . 1 6}$ & 0.01 \\
\hline & $(2.44)^{* * *}$ & $(0.43)$ & $(0.99)$ & $(2.95) * * *$ & $(0.17)$ \\
\hline \multirow{2}{*}{$\begin{array}{l}\text { Confidence in judicial protection in } \\
\text { disputes with other firms (no }=1 \text { ) }\end{array}$} & 0.03 & 0.06 & 0.12 & 0.05 & 0.06 \\
\hline & $(0.63)$ & $(1.12)$ & $(2.45)^{* *}$ & $(0.96)$ & $(1.00)$ \\
\hline \multirow{2}{*}{$\begin{array}{l}\text { Confidence in judicial protection in } \\
\text { disputes with state (no }=1 \text { ) }\end{array}$} & 0.01 & -0.10 & $\mathbf{0 . 1 0}$ & -0.03 & -0.11 \\
\hline & $(0.09)$ & $(2.18)^{* * *}$ & $(2.28)^{* *}$ & $(0.60)$ & $(2.29)^{* * *}$ \\
\hline \multirow[t]{2}{*}{ Engagement in tax evasion (yes $=1$ ) } & 0.05 & 0.04 & 0.01 & 0.09 & 0.01 \\
\hline & (1.07) & (1.01) & $(0.20)$ & $(1.89)^{*}$ & (017) \\
\hline \multirow{2}{*}{ Corruption as obstacle (important $=1$ ) } & 0.06 & 0.06 & -0.04 & 0.05 & 0.07 \\
\hline & $(1.35)$ & $(1.34)$ & $(0.80)$ & $(1.11)$ & $(1.50)$ \\
\hline \multirow{2}{*}{$\begin{array}{l}\text { Lack of safety as obstacle (important } \\
=1 \text { ) }\end{array}$} & 0.01 & 0.05 & -0.06 & -0.08 & 0.04 \\
\hline & $(0.26)$ & $(0.87)$ & (1.09) & $(1.44)$ & $(0.72)$ \\
\hline Age (founded in 1992 or later $=1$ ) & 0.08 & 0.03 & -0.01 & -0.01 & 0.01 \\
\hline
\end{tabular}




\begin{tabular}{|c|c|c|c|c|c|}
\hline & $(1.68) *$ & $(0.58)$ & $(0.01)$ & $(0.14)$ & $(0.21)$ \\
\hline \multirow[t]{2}{*}{ Location (countryside $=1$ ) } & -0.12 & -0.19 & 0.08 & 0.03 & -0.20 \\
\hline & $(1.65)^{*}$ & $(2.11)^{* *}$ & $(1.24)$ & $(0.36)$ & $(2.27)^{* *}$ \\
\hline Regions & included & included & included & included & included \\
\hline Industries & included & included & included & included & included \\
\hline $\mathrm{N}$ of observations & 573 & 574 & 569 & 554 & 488 \\
\hline Pseudo R2 & 0.14 & 0.28 & 0.16 & 0.13 & 0.28 \\
\hline
\end{tabular}

Notes: ${ }^{*}$ significant at $0.1^{* *}$ significant at $0.05^{* * *}$ significant at 0.01 . Robust $\mathrm{z}$-statistics in parentheses. 
Table 9 Probit regressions for the characteristics of firms' investment and innovation behavior (marginal effects, specification with the binary index of the insecurity of property rights)

\begin{tabular}{|c|c|c|c|c|c|}
\hline Variable & $\begin{array}{c}\text { Large } \\
\text { investments }\end{array}$ & Innovations & $\begin{array}{l}\text { Provision of } \\
\text { customer } \\
\text { credit }\end{array}$ & $\begin{array}{l}\text { Investment } \\
\text { projects for } \\
\text { the next year }\end{array}$ & $\begin{array}{c}\text { Use of long- } \\
\text { term } \\
\text { strategic } \\
\text { planning }\end{array}$ \\
\hline \multirow{2}{*}{$\begin{array}{l}\text { Integral index of the insecurity of } \\
\text { property rights (binary) }\end{array}$} & -0.08 & -0.08 & -0.11 & -0.09 & -0.09 \\
\hline & $(1.99)^{* * *}$ & $(1.93)^{*}$ & $(2.59) * *$ & $(\mathbf{2 . 0 0 )} * *$ & $(1.99)^{* * *}$ \\
\hline \multirow[t]{2}{*}{ State ownership (yes $=1$ ) } & -0.04 & -0.11 & -0.23 & 0.07 & -0.11 \\
\hline & $(0.49)$ & (1.46) & $(2.76)^{* * *}$ & $(0.76)$ & $(1.47)$ \\
\hline \multirow[t]{2}{*}{ Foreign ownership (yes = 1) } & 0.04 & 0.03 & -0.05 & -0.00 & -0.02 \\
\hline & $(0.64)$ & $(0.46)$ & $(0.90)$ & $(0.05)$ & $(0.24)$ \\
\hline \multirow{2}{*}{$\begin{array}{l}\text { Insider (managerial) ownership (yes = } \\
\text { 1) }\end{array}$} & -0.01 & 0.08 & -0.01 & 0.01 & 0.03 \\
\hline & $(0.29)$ & $(\mathbf{1 . 9 5})^{* * *}$ & $(0.13)$ & $(0.26)$ & $(0.73)$ \\
\hline \multirow[t]{2}{*}{ Financial condition (poor $=1$ ) } & -0.11 & -0.00 & -0.01 & -0.11 & -0.01 \\
\hline & $(2.25) * *$ & $(0.05)$ & $(0.15)$ & $(1.95) *$ & $(0.13)$ \\
\hline \multirow{2}{*}{ Ln number of employees } & 0.08 & 0.11 & 0.05 & 0.04 & 0.09 \\
\hline & $(3.71)^{* * *}$ & $(4.90)^{* * *}$ & $(2.28) * *$ & $(1.75)^{*}$ & $(4.06)^{* * *}$ \\
\hline \multirow[t]{2}{*}{ Market competition (high = 1) } & -0.04 & 0.05 & 0.18 & -0.07 & 0.04 \\
\hline & $(0.79)$ & $(1.09)$ & $(3.56) * * *$ & $(1.29)$ & $(0.81)$ \\
\hline \multirow[t]{2}{*}{ Sales for export (yes $=1$ ) } & -0.01 & 0.17 & 0.06 & 0.02 & 0.16 \\
\hline & $(0.12)$ & $(3.58)^{* * *}$ & $(1.30)$ & $(0.38)$ & $(3.15)^{* * *}$ \\
\hline \multirow{2}{*}{$\begin{array}{l}\text { Financial aid from the federal } \\
\text { authorities (yes }=1 \text { ) }\end{array}$} & 0.02 & $\mathbf{0 . 1 3}$ & 0.08 & 0.19 & 0.08 \\
\hline & $(0.26)$ & $(1.67)^{*}$ & $(1.02)$ & $(2.40)^{* *}$ & $(1.02)$ \\
\hline \multirow{2}{*}{$\begin{array}{l}\text { Financial aid from regional or local } \\
\text { authorities (yes }=1 \text { ) }\end{array}$} & 0.21 & 0.02 & 0.03 & -0.06 & 0.02 \\
\hline & $(3.70) * * *$ & $(0.33)$ & $(0.52)$ & $(0.88)$ & $(0.37)$ \\
\hline \multirow{2}{*}{$\begin{array}{l}\text { Financing social projects run by } \\
\text { regional or local authorities (yes }=1 \text { ) }\end{array}$} & 0.08 & 0.07 & 0.04 & 0.05 & 0.07 \\
\hline & $(1.65)^{*}$ & $(1.27)$ & $(0.81)$ & $(0.93)$ & $(1.25)$ \\
\hline \multirow[t]{2}{*}{ Recent litigation experience (yes $=1$ ) } & 0.13 & 0.01 & 0.06 & 0.15 & 0.04 \\
\hline & $(2.90) * * *$ & $(0.11)$ & $(1.29)$ & $(\mathbf{2 . 8 5})^{* * *}$ & $(0.65)$ \\
\hline \multirow{2}{*}{$\begin{array}{l}\text { Confidence in judicial protection in } \\
\text { disputes with other firms }(\text { no }=1)\end{array}$} & -0.01 & 0.03 & 0.09 & -0.01 & 0.03 \\
\hline & $(0.13)$ & $(0.68)$ & $(2.06)^{* * *}$ & $(0.10)$ & $(0.51)$ \\
\hline \multirow{2}{*}{$\begin{array}{l}\text { Confidence in judicial protection in } \\
\text { disputes with state }(\text { no }=1)\end{array}$} & 0.04 & -0.05 & 0.09 & 0.00 & -0.06 \\
\hline & $(0.79)$ & $(1.19)$ & $(2.23)^{* * *}$ & $(0.03)$ & $(1.20)$ \\
\hline \multirow[t]{2}{*}{ Engagement in tax evasion (yes $=1$ ) } & 0.05 & 0.03 & -0.00 & 0.11 & -0.01 \\
\hline & $(1.26)$ & $(0.66)$ & $(0.02)$ & $(2.43) * *$ & $(0.20)$ \\
\hline \multirow{2}{*}{ Corruption as obstacle (important $=1$ ) } & 0.06 & 0.04 & -0.01 & 0.07 & 0.06 \\
\hline & $(1.53)$ & $(1.02)$ & $(0.21)$ & $(1.26)$ & $(1.25)$ \\
\hline \multirow{2}{*}{$\begin{array}{l}\text { Lack of safety as obstacle (important } \\
=1 \text { ) }\end{array}$} & -0.03 & 0.06 & -0.03 & -0.10 & 0.06 \\
\hline & $(0.55)$ & (1.09) & $(0.62)$ & $(1.80)^{*}$ & $(1.10)$ \\
\hline \multirow[t]{2}{*}{ Age (founded in 1992 or later $=1$ ) } & 0.04 & 0.01 & -0.01 & 0.00 & 0.00 \\
\hline & $(0.92)$ & $(0.18)$ & $(0.14)$ & $(0.02)$ & $(0.05)$ \\
\hline \multirow{2}{*}{ Location (countryside $=1$ ) } & \begin{tabular}{|c|}
-0.13 \\
\end{tabular} & -0.22 & 0.12 & 0.09 & $\begin{array}{l}-0.23 \\
\end{array}$ \\
\hline & $(1.84) *$ & $(2.54)^{* *}$ & $(1.82)^{*}$ & $(1.05)$ & $(2.78)^{* * *}$ \\
\hline
\end{tabular}




\begin{tabular}{|l|c|c|c|c|c|}
\hline Regions & included & included & included & included & included \\
\hline Industries & included & included & included & included & included \\
\hline N of observations & 641 & 642 & 633 & 615 & 541 \\
\hline Pseudo R2 & 0.13 & 0.24 & 0.15 & 0.12 & 0.26 \\
\hline
\end{tabular}

Notes: ${ }^{*}$ significant at $0.1 * *$ significant at $0.05^{* * *}$ significant at 0.01. Robust $z$-statistics in parentheses. 
APENDIX

Table A1. General characteristics of the HSE-Levada sample

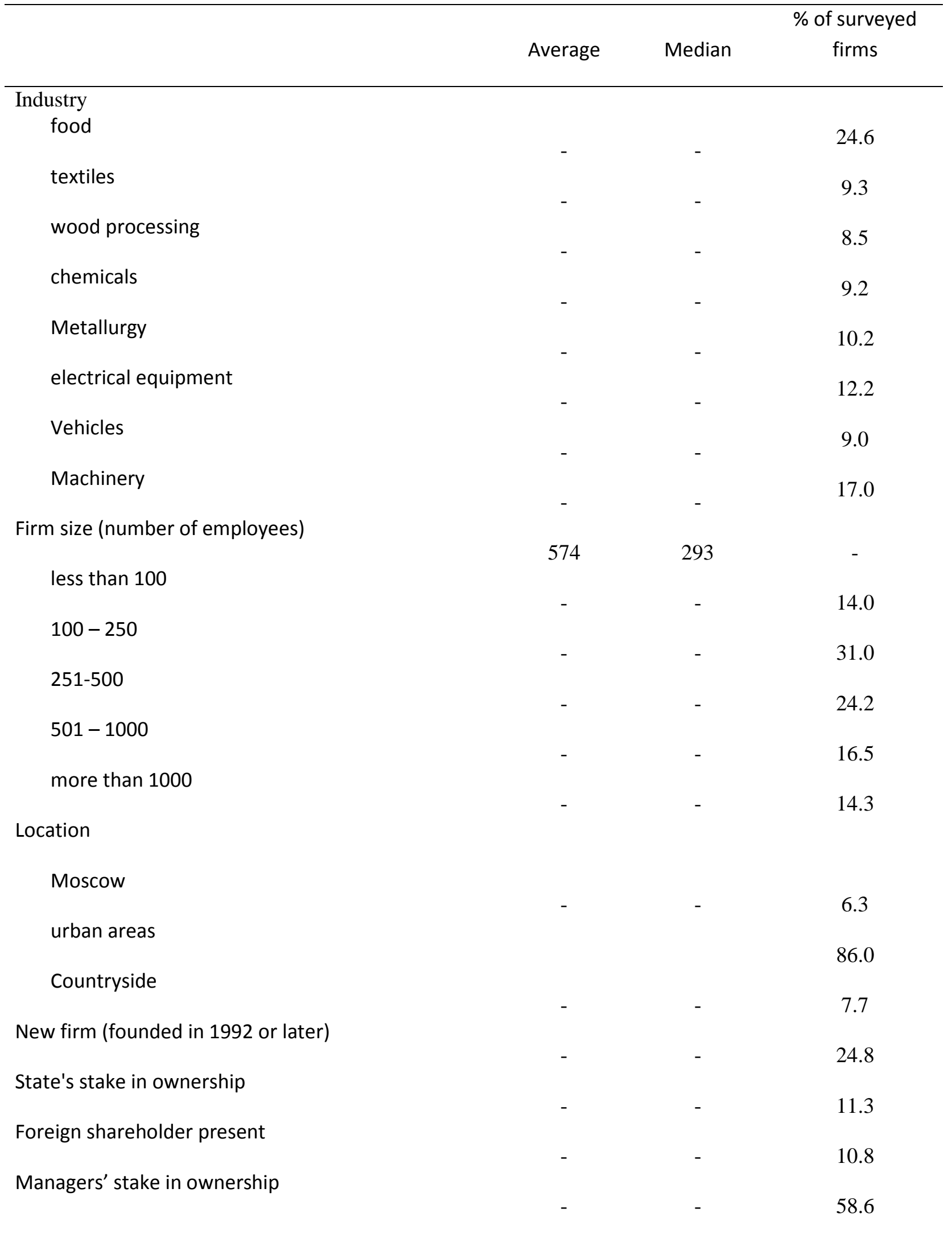




\section{Exporter}

Market competition

low

High

Financial condition

Poor

Satisfactory

Good

Subsidising from the federal budget

$0.10 \quad 0$

Subsidising from the local/regional budgets

Financing social projects run by regional or local

0.17

0.77 authorities

Recent litigation experience

0.74

Lack of confidence in judicial protection in disputes

0.26

with other firms

Lack of confidence in judicial protection in disputes

with state

Engagement in tax evasion

Corruption as obstacle

0.40

Lack of safety as obstacle

0.19

Investment in 2008

$0.24 \quad 0$

Recent innovations

Provision of customer credit

0.71

Investment projects for the next year

$0.33 \quad 0$

Long-term strategic planning

$0.28 \quad 0$

Sales per worker in $2008, .000$ rubles

Average monthly wage, rubles

$13,572 \quad 12,000$

N 
Table A2. Description and construction of the institutional variables

\begin{tabular}{|c|c|c|c|}
\hline No & Question & Scale & Variable \\
\hline $36 f$. & $\begin{array}{l}\text { How serious an obstacle for operation and } \\
\text { growth of your business is CORRUPTION? }\end{array}$ & $\begin{array}{l}\text { 1-5 (1- not an } \\
\text { obstacle, } 5 \text { - very } \\
\text { serious obstacle), } \\
\text { recoded as binary }\end{array}$ & $\begin{array}{l}\text { Corruption (equals } 0 \text { if initial } \\
\text { values were } 1 \text { or } 2 \text { and equals } 1 \\
\text { if these values were } 3,4 \text { or } 5 \text { ) }\end{array}$ \\
\hline $36 g$. & $\begin{array}{l}\text { How serious an obstacle for operation and } \\
\text { growth of your business is LACK OF PERSONAL } \\
\text { SAFETY (theft, racket, terrorism etc)? }\end{array}$ & $\begin{array}{l}\text { 1-5 (1- not an } \\
\text { obstacle, } 5 \text { - very } \\
\text { serious obstacle), } \\
\text { recoded as binary }\end{array}$ & $\begin{array}{l}\text { Lack of personal safety (equals } 0 \\
\text { if initial values were } 1 \text { or } 2 \text { and } \\
\text { equals } 1 \text { if these values were } 3 \text {, } \\
4 \text { or } 5 \text { ) }\end{array}$ \\
\hline $37 a$. & $\begin{array}{l}\text { To what extent do you agree with the } \\
\text { statement that in the case of disputes with } \\
\text { OTHER FIRMS courts would be able to protect } \\
\text { your legal interests in the sphere of property } \\
\text { rights and contract enforcement? }\end{array}$ & $\begin{array}{l}\text { 1-4 (1 - fully agree, } 4- \\
\text { fully disagree), recoded } \\
\text { as binary }\end{array}$ & $\begin{array}{l}\text { Confidence in judicial protection } \\
\text { in disputes with other firms } \\
\text { (equals } 0 \text { if initial values were } 1 \\
\text { or } 2 \text { and equals } 1 \text { if they were } 3 \\
\text { or } 4 \text { ) }\end{array}$ \\
\hline $37 b$. & $\begin{array}{l}\text { To what extent do you agree with the } \\
\text { statement that in the case of disputes with THE } \\
\text { STATE courts would be able to protect your } \\
\text { legal interests in the sphere of property rights } \\
\text { and contract enforcement? }\end{array}$ & $\begin{array}{l}\text { 1-4 (1- fully agree, } 4- \\
\text { fully disagree), recoded } \\
\text { as binary }\end{array}$ & $\begin{array}{l}\text { Confidence in judicial protection } \\
\text { in disputes with state (equals } 0 \\
\text { if initial values were } 1 \text { or } 2 \text { and } \\
\text { equals } 1 \text { if they were } 3 \text { or } 4 \text { ) }\end{array}$ \\
\hline 38. & $\begin{array}{l}\text { Did your firm participate in litigations as } \\
\text { DEFENDANT OR PLAINTIFF during 2005-08? }\end{array}$ & $1-$ yes, $0-$ no & Recent litigation experience \\
\hline 40. & $\begin{array}{l}\text { Many firms are not in a position to pay taxes } \\
\text { fully and for this reason underreport their } \\
\text { proceeds. In your opinion, on average how big } \\
\text { is this UNDERREPORTING OF PROCEEDS IN } \\
\text { YOUR INDUSTRY (as a percentage of the actual } \\
\text { proceeds, approximate estimate)? }\end{array}$ & $\begin{array}{l}\text { Percent, recoded as } \\
\text { binary }\end{array}$ & $\begin{array}{l}\text { Engagement in tax evasion } \\
\text { (equals } 1 \text { if at least one of } \\
\text { responses to questions } 40 \text { and }\end{array}$ \\
\hline 41. & $\begin{array}{l}\text { Many firms are not in a position to pay tax on } \\
\text { profit in full and for this reason over-report } \\
\text { their costs. In your opinion, on average how big } \\
\text { is this OVERREPORTING OF COSTS IN YOUR } \\
\text { INDUSTRY (as a percentage of the actual costs, } \\
\text { approximate estimate)? }\end{array}$ & $\begin{array}{l}\text { Percent, recoded as } \\
\text { binary }\end{array}$ & $\begin{array}{l}41 \text { was positive and equals } 0 \text { if } \\
\text { responses to were "zero } \\
\text { percent") }\end{array}$ \\
\hline 46. & $\begin{array}{l}\text { Did your firm provide SUPPORT FOR SOCIAL } \\
\text { PROJECTS run by the local or regional } \\
\text { authorities during } 2007-08 \text { (financing social } \\
\text { infrastructure or housing, sponsoring } \\
\text { regional/municipal programs etc)? }\end{array}$ & $1-$ yes, $0-$ no & $\begin{array}{l}\text { Financing social projects run by } \\
\text { regional or local authorities }\end{array}$ \\
\hline
\end{tabular}


Table A3. Comparative characteristics of the sub-samples of firms included in or excluded from the analysis

\begin{tabular}{|c|c|c|}
\hline Variables & $\begin{array}{l}\text { Sub-sample of firms } \\
\text { included in analysis }\end{array}$ & $\begin{array}{l}\text { Sub-sample of firms } \\
\text { excluded from analysis }\end{array}$ \\
\hline $\begin{array}{l}\text { Additive index of insecurity of property rights, } \\
\text { average }\end{array}$ & 0.51 & 0.54 \\
\hline $\begin{array}{l}\text { Binary index of insecurity of property rights, } \\
\text { average }\end{array}$ & 0.34 & 0.37 \\
\hline Share of firms with state's stake in ownership, \% & 8 & 14 \\
\hline Share of firms with foreign shareholders, \% & 11 & 10 \\
\hline $\begin{array}{l}\text { Share of firms with managers' stake in ownership, } \\
\%\end{array}$ & 50 & 40 \\
\hline Ln number of employees, average & 5.74 & 5.51 \\
\hline Share of firms in poor financial condition, \% & 18 & 12 \\
\hline Share of firms facing intense market competition, \% & 79 & 74 \\
\hline Share of exporters, $\%$ & 57 & 48 \\
\hline $\begin{array}{l}\text { Share of firms receiving subsidies from the federal } \\
\text { budget }\end{array}$ & 10 & 10 \\
\hline $\begin{array}{l}\text { Share of firms receiving subsidies from } \\
\text { local/regional budgets }\end{array}$ & 17 & 16 \\
\hline $\begin{array}{l}\text { Share of firms financing social projects run by } \\
\text { regional or local authorities, } \%\end{array}$ & 79 & 73 \\
\hline Share of firms with recent litigation experience, $\%$ & 78 & 65 \\
\hline $\begin{array}{l}\text { Share of firms non-confident in judicial protection } \\
\text { in disputes with other firms, } \%\end{array}$ & 28 & 21 \\
\hline $\begin{array}{l}\text { Share of firms non-confident in judicial protection } \\
\text { in disputes with state, } \%\end{array}$ & 51 & 53 \\
\hline $\begin{array}{l}\text { Share of firms supposedly engaged in tax evasion, } \\
\%\end{array}$ & 47 & 54 \\
\hline Share of firms considering corruption as obstacle, $\%$ & 42 & 34 \\
\hline $\begin{array}{l}\text { Share of firms considering lack of safety as } \\
\text { obstacle, } \%\end{array}$ & 20 & 18 \\
\hline
\end{tabular}




\begin{tabular}{|l|c|c|}
\hline Share of new firms (founded in 1992 or later), \% & 26 & 21 \\
\hline Share of firms located in the countryside, \% & 7 & 24 \\
\hline Food, \% & 25 & 10 \\
\hline Textile, \% & 9 & 8 \\
\hline Wood processing, \% & 9 & 10 \\
\hline Chemicals, \% & 11 & 15 \\
\hline Metallurgy, \% & 11 & 8 \\
\hline Electrical equipment, \% & 9 & 17 \\
\hline Vehicles, \% & 17 & 7 \\
\hline Machinery, \% & 6 & 9 \\
\hline Share of firms located in Moscow, \% & 7 & \\
\hline Share of firms located in the countryside, \% & & \\
\hline
\end{tabular}


Table A4. Heckman estimates for the additive index of the insecurity of property rights

\begin{tabular}{|c|c|c|}
\hline & Main equation & Selection equation \\
\hline \multirow[t]{2}{*}{ State ownership (yes $=1$ ) } & 0.54 & 0.11 \\
\hline & $(4.18)^{* * * *}$ & $(0.39)$ \\
\hline \multirow[t]{2}{*}{ Foreign ownership (yes $=1$ ) } & -0.08 & 0.12 \\
\hline & $(0.76)$ & $(0.51)$ \\
\hline \multirow{2}{*}{ Insider (managerial) ownership (yes $=1$ ) } & 0.9 & 0.27 \\
\hline & $(1.45)$ & $(1.92)^{*}$ \\
\hline \multirow{2}{*}{ Financial condition $($ poor $=1)$} & 0.19 & 0.14 \\
\hline & $(2.24) * *$ & $(0.72)$ \\
\hline \multirow[t]{2}{*}{ Ln number of employees } & -0.07 & 0.05 \\
\hline & (2.09)* & $\begin{array}{l}(0.57) \\
\end{array}$ \\
\hline \multirow{2}{*}{ Market competition (high $=1$ ) } & 0.16 & 0.12 \\
\hline & $(1.99)^{*}$ & $(0.73)$ \\
\hline \multirow{2}{*}{ Sales for export (yes $=1$ ) } & -0.09 & 0.08 \\
\hline & $(1.20)$ & $\begin{array}{l}(0.46) \\
\end{array}$ \\
\hline \multirow{2}{*}{$\begin{array}{l}\text { Financial aid from the federal authorities } \\
\text { (yes = 1) }\end{array}$} & 0.01 & -0.06 \\
\hline & $(0.11)$ & $(0.37)$ \\
\hline \multirow{2}{*}{$\begin{array}{l}\text { Financial aid from regional or local } \\
\text { authorities (yes }=1 \text { ) }\end{array}$} & 0.05 & -0.14 \\
\hline & (0.58) & $(0.70)$ \\
\hline \multirow{2}{*}{$\begin{array}{l}\text { Financing social projects run by regional } \\
\text { or local authorities (yes }=1 \text { ) }\end{array}$} & $\mathbf{0 . 1 7}$ & 0.16 \\
\hline & $(2.09)^{*}$ & $(0.83)$ \\
\hline \multirow[t]{2}{*}{ Recent litigation experience (yes $=1$ ) } & 0.14 & 0.14 \\
\hline & $(1.80)^{*}$ & $(0.85)$ \\
\hline \multirow{2}{*}{$\begin{array}{l}\text { Confidence in judicial protection in } \\
\text { disputes with other firms }(\text { no }=1)\end{array}$} & -0.10 & -0.06 \\
\hline & (1.32) & $(0.37)$ \\
\hline \multirow{2}{*}{$\begin{array}{l}\text { Confidence in judicial protection in } \\
\text { disputes with state }(\text { no }=1)\end{array}$} & 0.12 & -0.16 \\
\hline & $(1.70)^{*}$ & (1.05) \\
\hline \multirow[t]{2}{*}{ Engagement in tax evasion (yes $=1$ ) } & 0.14 & -0.20 \\
\hline & $(2.13)^{*}$ & $(1.36)$ \\
\hline \multirow[t]{2}{*}{ Corruption as obstacle (important $=1$ ) } & 0.15 & 0.33 \\
\hline & $(2.10)^{* *}$ & $(2.20)^{*}$ \\
\hline \multirow[t]{2}{*}{ Lack of safety as obstacle (important $=1$ ) } & 0.38 & -0.19 \\
\hline & $(4.44)^{* * *}$ & $(1.48)$ \\
\hline \multirow[t]{2}{*}{ Age (founded in 1992 or later $=1$ ) } & -0.05 & 0.33 \\
\hline & $(0.64)$ & $(2.02)^{*}$ \\
\hline \multirow[t]{2}{*}{ Location (countryside $=1$ ) } & 0.22 & -0.04 \\
\hline & $(1.73)^{*}$ & $(0.15)$ \\
\hline Regions & included & Included \\
\hline
\end{tabular}




\begin{tabular}{|l|c|c|}
\hline Industry & included & Included \\
\hline Constant & 0.19 & $\mathbf{0 . 7 4}$ \\
\cline { 2 - 3 } & $(1.22)$ & $\mathbf{( 2 . 3 8 ) ^ { * * }}$ \\
\hline N of observations & 582 & -0.09 \\
\hline athrho & & $(0.16)$ \\
\hline LR test of indep. eqns. (rho $=0):$ & \multicolumn{2}{|c|}{ chi2(1) $=0.24$ Prob $>0.627$} \\
\hline
\end{tabular}

